OPEN ACCESS

Edited by:

Saleem Mustafa,

Universiti Malaysia Sabah, Malaysia

Reviewed by:

Moha Esmaeili,

University of Tasmania, Australia

Andrew J. Sinclair,

Deakin University, Australia

*Correspondence:

Brian C. Small

bcsmall@uidaho.edu

Specialty section:

This article was submitted to

Water-Smart Food Production,

a section of the journal

Frontiers in Sustainable Food Systems

Received: 16 December 2021

Accepted: 08 February 2022

Published: 04 March 2022

Citation:

Hong J, Bledsoe JW, Overturf KE,

Lee $S$, lassonova $D$ and Small BC

(2022) Latitude ${ }^{T M}$ Oil as a Sustainable Alternative to Dietary Fish Oil in

Rainbow Trout (Oncorhynchus

mykiss): Effects on Filet Fatty Acid

Profiles, Intestinal Histology, and

Plasma Biochemistry.

Front. Sustain. Food Syst. 6:837628.

doi: 10.3389/fsufs. 2022.837628

\section{Latitude $^{\mathrm{TM}}$ Oil as a Sustainable Alternative to Dietary Fish Oil in Rainbow Trout (Oncorhynchus mykiss): Effects on Filet Fatty Acid Profiles, Intestinal Histology, and Plasma Biochemistry}

\author{
Jeongwhui Hong ${ }^{1}$, Jacob W. Bledsoe ${ }^{1,2}$, Kenneth E. Overturf ${ }^{3}$, Seunghan Lee ${ }^{1,4}$, \\ Diliara lassonova ${ }^{5}$ and Brian C. Small ${ }^{1 *}$
}

${ }^{1}$ Aquaculture Research Institute, Hagerman Fish Culture Experiment Station, University of Idaho, Hagerman, ID, United States, ${ }^{2}$ United States Department of Agriculture National Cold Water Marine Aquaculture Center, Franklin, ME, United States, ${ }^{3}$ United States Department of Agriculture/Agriculture Research Service Trout Grains Program, Hagerman Fish Culture Experiment Station, Hagerman, ID, United States, ${ }^{4}$ Aquafeed Research Center, National Institute of Fisheries Science, Pohang, South Korea, ${ }^{5}$ Cargill Incorporated, Minneapolis, MN, United States

The aim of this study was to evaluate the effects of Latitude ${ }^{\text {TM }}$ oil (transgenic canola) fed to rainbow trout, Oncorhynchus mykiss, for 52 weeks on growth performance, non-specific immune responses, histology, and filet omega-3 fatty acid content. Latitude $^{\mathrm{TM}}$ oil (LO) has high lipid digestibility (93\%), and contains omega-3 fatty acids eicosapentaenoic acid (EPA, C20:5n-3), docosapentaenoic acid (DPA, C22:5n-3), and docosahexaenoic acid (DHA, C22:6n-3). Three isonitrogenous (49\%), isolipidic (20\%) and isocaloric (24.2 $\left.\mathrm{MJ} \mathrm{kg}^{-1}\right)$ diets differing by lipid source $(0,8$, or $16 \% \mathrm{LO}$, replacing fish oil and poultry fat) were fed over an entire production cycle beginning with $19 \mathrm{~g}$ juvenile fish. At the end of the 52-week feeding trial, final body weight, weight gain and specific growth rate of fish fed 8\% LO (LO-8) and 16\% LO (LO-16) diets were significantly higher than those fed the 0\% LO (LO-0) diet $(P<0.05)$. Phagocytic respiratory burst in fish fed the LO-16 diet was significantly higher than those fish fed the other 2 diets $(P$ $<0.05)$. There were no differences in superoxide dismutase, catalase and lysozyme. Histological examination of the distal intestine indicated reduced inflammation in fish fed the LO-8 diet but not the LO-O and LO-16 diets. Filet DHA content of fish fed the LO-8 and LO-16 diets were similar to those of fish fed the LO-0 diet. As these diets had lower DHA content, this suggests dietary EPA and DPA from LO was converted to DHA and deposited in the filet. This is supported by increased expression of genes involved in fatty acid elongation, desaturation and beta oxidation in both liver and muscle of fish fed LO $(P<0.05)$. Total EPA+DHA content of the edible filet ranged between 1,079-1,241 mg $100 \mathrm{~g}^{-1}$ across treatments, each providing the recommended daily intake for human consumption (500-1,000 mg day $\left.{ }^{-1}\right)$. Overall, this study demonstrated that LO fed over an entire production period is a highly digestible lipid source suitable and sustainable for meeting the fatty acid requirements of rainbow trout, as well as consumer expectations for filet omega-3 fatty acid content.

Keywords: Latitude oil, transgenic canola oil, sustainable feeds, fish oil, rainbow trout 


\section{INTRODUCTION}

Over the past decade, dramatic increases in fishmeal (FM) and fish oil (FO) prices have driven feed manufacturers across the aquaculture industry to lower the use of FM and FO in aquafeed for virtually all farmed fish species. For salmonid diets, this has meant a reduction of marine ingredients in the diet by as much as 60\% (Ytrestøyl et al., 2015). The transition away from marine ingredients toward plant-based ingredients has afforded the industry the ability to increase production while reducing feed costs and the impact of aquaculture on wild fisheries. However, it is not without costs, in that it has resulted in a substantial reduction in the levels of omega-3 long-chain polyunsaturated fatty acids (n-3 LC-PUFA), specifically eicosapentaenoic acid (EPA, C20:5n-3) and docosahexaenoic acid (DHA, C22:6n-3) in fish tissues. Therefore, it is significantly vital to produce more sustainable oil sources that can be used to meet the increasing demand for oil ingredients high in n-3 LC-PUFA.

Marine microalgae that are able to synthesize EPA and DHA directly are the world's primary producers of these fatty acids, which are then accumulated through the aquatic food webs. For this reason, fish is considered the primary dietary source of n3 LC-PUFA, EPA and DHA for humans (Betancor et al., 2017; Osmond and Colombo, 2019). Many health agencies worldwide recommend $500-1000 \mathrm{mg}$ day $^{-1}$ of total EPA + DHA for reducing cardiovascular disease (Aranceta and Pérez-Rodrigo, 2012).

There is considerable interest in novel sources of n-3 LCPUFA to supplement the limited supplies of fish oil. These sources include other marine organisms such as krill or copepods, fermentation of algae, and the genetic engineering of microbes such as yeasts (Napier et al., 2019; Betancor et al., 2021). However, these technologies pose economic challenges for mass production (Betancor et al., 2017; Tocher et al., 2019; Fabris et al., 2020). Recently, genetically modified canola oil has emerged as an alternative and sustainable oil source for aquafeed. Transgenic canola oil contains arachidonic acid (ARA, C20:4n-6) ( 2.3\%), EPA ( 9.1\%), docosapentaenoic acid (DPA, C22:5n-3) ( 2.3\%) and DHA $(\sim 0.9 \%)$, which is uncommon in other terrestrial oils. This oil has recently been used as a component of a terrestrial oil blend ( $40 \%$ transgenic canola oil) in rainbow trout (Oncorhynchus mykiss) and has shown no adverse effects on growth performance (Hossain et al., 2021).

DPA is an indispensable n-3 LC-PUFA found in large amounts in FO, and even larger amounts in salmon filets (0.4 g 100 $\mathrm{g}^{-1}$ filet) (Calder, 2018; Lozano-Muñoz et al., 2020). DPA has attracted recent attention due to its importance in human health. DPA has been found to be a crucial component of phospholipids found in animal cell membranes and shown to lower plasma cholesterol levels (Kaur et al., 2016; Drouin et al., 2019). In addition, it has been reported that DPA reduces the expression of inflammatory genes (Backes et al., 2016). DPA is an intermediate between EPA and DHA in the n-3 LC-PUFA pathway, which may act as a reservoir for EPA and DHA (Dyall, 2015) and is of current interest for its putative capacity to either be converted to DHA or retro-converted to EPA (Drouin et al., 2019). In vertebrates, the synthesis of DHA from ALA requires three desaturation and three elongation steps (Sprecher, 2000). First, synthesis of EPA from $\alpha$-linolenic acid (ALA, C18:3n-3) is achieved by $\triangle 6 \mathrm{fad}$ to produce C18:4n-3 that is elongated to C20:4n-3 followed by $\triangle 5$ fad. Then, elovl2 and elovl5 are required for elongation of EPA to DPA. Next, DPA is elongated to C24:5n-3 by elovl2 and elovl5, then desaturated to $24: 6 n-3$ by $\Delta 6 f a d$, and finally converted to DHA by a peroxisomal chain shortening step (Li et al., 2010; Gregory and James, 2014).

Rainbow trout (Oncorhynchus mykiss) is a commercially important salmonid species and an experimental model species since this species requires LC-PUFAs due to limited ability to convert ALA to EPA or DHA. The total n-3 LC-PUFA dietary requirements of rainbow trout and Atlantic salmon, including ALA, EPA, and DHA has been reported to range from 0.4$2.0 \%$ of the diet (NRC, 2011). These estimates were determined based on the amount required to prevent classical deficiency and nutritional pathology, and many of these studies were performed on small fish fed diets low in lipid for relatively short periods of time (Tocher, 2015). However, it has been proposed that modern high-energy (lipid) diets and higher fish growth rates necessitate a reassessment of these requirements (NRC, 2011), suggesting that higher requirements for essential fatty acids (EFA) may now exist to support faster growth and optimum health over the entire production cycle of the fish (Tocher, 2015; Bou et al., 2017). Furthermore, some suggest the requirement should not be set only for optimal fish growth and health, but also to meet the daily recommended n-3 LC-PUFA intake for human consumers (Simopoulos, 2000; Tocher, 2009).

The aim of this study was to evaluate a new transgenic canola oil containing EPA, DPA and DHA as a substitute for FO in rainbow trout feeds reflecting current commercial feed formulation in terms of growth performance, health and n-3 LC-PUFA composition over a complete production cycle, from fingerling to market weight. We hypothesized that Latitude oil (LO) containing high EPA and DPA would effectively replace fish oil in trout feeds without detrimental impact on fish performance. Furthermore, we hypothesized that filet EPA+DHA level of fish fed LO-8 or LO-16 would be similar to filet EPA+DHA content of fish fed LO-0 diet meeting or exceeding the recommended daily intake of EPA + DHA for consumers. To our knowledge, there are no reported studies on transgenic canola oil throughout the entire production cycle in rainbow trout. The ultimate objective was to formulate feeds that not only support early growth, but improve long-term health and survival of the fish, and result in a product that meets the nutritional needs of consumers while being sourced from more environmentally and economically sustainable sources.

\section{MATERIALS AND METHODS}

\section{Experimental Design and Diets}

Three experimental diets were prepared and extruded (Bozeman Fish Technology Center, Bozeman, MT) in various sizes from 2.5 to $4.5 \mathrm{~mm}$, and were formulated to be isonitrogenous $(49 \%$ crude protein), isolipidic (20\% crude lipid) and isocaloric (24.2 MJ $\mathrm{kg}^{-1}$ ): a control diet (FO 6.43\%, Poultry fat 9.57\%) and two experimental diets that replace FO by 50 or $100 \%$ with 
TABLE 1 | Formulation and proximate composition of the experimental diets (as fed).

\begin{tabular}{|c|c|c|c|}
\hline \multirow[t]{2}{*}{ Ingredients (\%) } & \multicolumn{3}{|c|}{ Diets } \\
\hline & LO-O & LO-8 & LO-16 \\
\hline Fish meal, sardine ${ }^{a}$ & 20.0 & 20.0 & 20.0 \\
\hline PBM, feed grade ${ }^{a}$ & 12.5 & 12.5 & 12.5 \\
\hline Soybean meal ${ }^{a}$ & 11.5 & 11.5 & 11.5 \\
\hline Soy protein concentrate ${ }^{b}$ & 5.5 & 5.5 & 5.5 \\
\hline Wheat gluten meal ${ }^{\mathrm{a}}$ & 1.5 & 1.5 & 1.5 \\
\hline Corn protein concentrate ${ }^{c}$ & 13.5 & 13.5 & 13.5 \\
\hline Wheat flour ${ }^{\mathrm{a}}$ & 16.2 & 16.2 & 16.2 \\
\hline Dicalcium phosphate ${ }^{a}$ & 1.4 & 1.4 & 1.4 \\
\hline Trace mineral mix ${ }^{d}$ & 0.1 & 0.1 & 0.1 \\
\hline Vitamin Premix & 1.0 & 1.0 & 1.0 \\
\hline Choline chloride $(60 \%)^{a}$ & 0.6 & 0.6 & 0.6 \\
\hline Stay C (35\%) vitamin ${ }^{\dagger}$ & 0.2 & 0.2 & 0.2 \\
\hline Fish oil ${ }^{\mathrm{a}}$ & 6.43 & 3.21 & 0.0 \\
\hline Poultry fat ${ }^{9}$ & 9.57 & 4.79 & 0.0 \\
\hline Latitude $^{T M}$ oil $^{h}$ & 0.00 & 8.00 & 16.0 \\
\hline \multicolumn{4}{|l|}{ Nutrients ( $\%$ as-fed basis) } \\
\hline Dry matter & 98.3 & 98.5 & 97.9 \\
\hline Protein & 50.0 & 49.4 & 49.6 \\
\hline Fat & 20.3 & 21.0 & 20.1 \\
\hline Ash & 3.66 & 3.54 & 3.14 \\
\hline Gross energy (MJ/kg) & 24.3 & 24.4 & 23.9 \\
\hline
\end{tabular}

${ }^{a}$ Rangen Inc., Buhl, ID, USA. ${ }^{b}$ Profine VF, The Solae Company, St. Louis, MO, USA. ${ }^{C}$ Empyreal ${ }^{\circledR} 75$, Cargill Corn Milling, Cargill, Inc., Blair, NE, USA. ${ }^{d}$ US Fish and Wildlife Service Trace Mineral Premix \#3 supplied the following ( $\mathrm{mg} \mathrm{kg}^{-1}$ diet): $\mathrm{Zn}$ (as ZnSO4.7H2O), 75; Mn (as MnSO4), 20; Cu (as CuSO4.5H2O), 1.54; I (as KIO3), 10. eVitamin premix supplied the following per $\mathrm{kg}$ diet: vitamin A, 2.4 mg; vitamin D, $0.15 \mathrm{mg}$; vitamin E, $267 \mathrm{mg}$; vitamin $\mathrm{K}$ as menadione sodium bisulfite, $20 \mu \mathrm{g}$; thiamin as thiamin mononitrate, $32 \mathrm{mg}$; riboflavin, $64 \mathrm{mg}$; pyridoxine as pyridoxine- $\mathrm{HCl}, 64 \mathrm{mg}$; pantothenic acid as Ca-d-pantothenate, $192 \mathrm{mg}$; niacin as nicotinic acid, $240 \mathrm{mg}$; biotin, $0.56 \mathrm{mg}$; folic acid, $12 \mathrm{mg}$; vitamin $B_{12}, 50 \mu \mathrm{g}$; and inositol as meso-inositol, $400 \mathrm{mg} .{ }^{f}$ Skretting USA, Tooele, UT, USA. ${ }^{9}$ Tyson Foods Inc., Springdale, AR, USA. ${ }^{h}$ Cargill Inc., Minneapolis, MN, USA.

LO. All three diets were formulated to reflect commercial feed formulations for rainbow trout and thus included 20\% FM. Poultry fat and LO were gifted by Tyson and Cargill, respectively. The three experimental diets were formulated to maintain $3 \%$ $\mathrm{EPA}+\mathrm{DHA}$ content (\% of the diet). To accomplish this, the following proportion of the oils were used, LO-0 $(6.43 \%$ FO $+9.57 \%$ Poultry fat), LO-8 $(3.21 \%$ FO $+4.79 \%$ Poultry fat + $8 \% \mathrm{LO})$ and LO-16 (16\% LO). The proximate and fatty acid composition of experimental diets are shown in Tables 1, 2. Although formulated to maintain 3\% EPA+DHA content, diets ranged from $2.78-3.32 \%$ of diet.

In vivo digestibility was determined for LO fed to rainbow trout. A reference diet containing practical ingredients and $0.1 \%$ yttrium oxide was prepared. A batch of test diet containing $20 \%$ test ingredient and $80 \%$ reference diet mash (combined on a drymatter basis) was prepared and analyzed. All ingredients for the digestibility trial were mixed and cold pelleted at the University of Idaho's Hagerman Fish Culture Experiment Stations (HFCES)
TABLE 2 | Analyzed fatty acid profile of the experimental diets ${ }^{a}$

\begin{tabular}{|c|c|c|c|c|c|c|}
\hline \multirow[b]{3}{*}{ Fatty acids } & \multicolumn{6}{|c|}{ Diet } \\
\hline & \multicolumn{2}{|c|}{ LO-O } & \multicolumn{2}{|c|}{ LO-8 } & \multicolumn{2}{|c|}{ LO-16 } \\
\hline & $\%$ FAME & \% Diet & $\%$ FAME & $\%$ Diet & $\%$ FAME & $\%$ Diet \\
\hline C14:0 & 1.93 & 0.39 & 1.19 & 0.25 & 0.38 & 0.08 \\
\hline C16:0 & 18.6 & 3.78 & 13.3 & 2.80 & 9.15 & 1.84 \\
\hline C18:0 & 5.52 & 1.12 & 4.81 & 1.01 & 3.84 & 0.77 \\
\hline C24:0 & 1.93 & 0.39 & 1.19 & 0.25 & 0.38 & 0.08 \\
\hline$\Sigma$ SFA & 28.0 & 5.68 & 20.5 & 4.31 & 13.7 & 2.76 \\
\hline C16:1n-7 & 7.10 & 1.44 & 4.30 & 0.90 & 1.39 & 0.28 \\
\hline C18:1n-9 & 29.0 & 5.89 & 27.5 & 5.76 & 26.6 & 5.34 \\
\hline C20:1n-9 & 2.35 & 0.48 & 1.71 & 0.36 & 0.95 & 0.19 \\
\hline C22:1n-9 & 1.17 & 0.24 & 0.66 & 0.14 & 0.14 & 0.03 \\
\hline$\Sigma$ MUFA & 39.6 & 8.04 & 34.1 & 7.17 & 29.1 & 5.84 \\
\hline C18:2n-6 & 15.0 & 3.04 & 20.3 & 4.26 & 25.9 & 5.21 \\
\hline C18:3n-6 & 0.16 & 0.03 & 0.99 & 0.21 & 1.90 & 0.38 \\
\hline C20:2n-6 & 0.15 & 0.03 & 0.12 & 0.02 & 0.09 & 0.02 \\
\hline C20:3n-6 & 0.13 & 0.03 & 1.27 & 0.27 & 2.48 & 0.50 \\
\hline C20:4n-6 (ARA) & 1.20 & 0.24 & 1.93 & 0.40 & 2.63 & 0.53 \\
\hline n-6 PUFA & 16.6 & 3.38 & 24.6 & 5.17 & 33.0 & 6.64 \\
\hline C18:3n-3 & 1.22 & 0.25 & 2.33 & 0.49 & 3.41 & 0.68 \\
\hline C20:5n-3 (EPA) & 7.39 & 1.50 & 10.3 & 2.17 & 13.1 & 2.64 \\
\hline C22:5n-3 (DPA) & 0.93 & 0.19 & 1.67 & 0.35 & 2.28 & 0.46 \\
\hline C22:6n-3 (DHA) & 6.29 & 1.28 & 5.00 & 1.05 & 3.38 & 0.68 \\
\hline $\mathrm{EPA}+\mathrm{DHA}$ & 13.7 & 2.78 & 15.3 & 3.22 & 16.5 & 3.32 \\
\hline n-3 PUFA & 15.8 & 3.21 & 19.3 & 4.06 & 22.2 & 4.46 \\
\hline$n-3 / n-6$ & \multicolumn{2}{|c|}{0.95} & \multicolumn{2}{|c|}{0.79} & \multicolumn{2}{|c|}{0.67} \\
\hline
\end{tabular}

aSFA, saturated fatty acids; MUFA, mono-unsaturated fatty acids; n-6 PUFA, n6 poly-unsaturated fatty acids; n-3 PUFA, n-3 poly-unsaturated fatty acids; ARA, arachidonic acid; EPA, eicosapentaenoic acid; DPA, docosapentaenoic acid; DHA, docosahexaenoic acid.

using a laboratory-scale California pellet mill fitted with a $4-\mathrm{mm}$ die. After $36 \mathrm{~h}$ drying in a hot-air dryer at $37^{\circ} \mathrm{C}$, the feeds were stored at ambient temperature $\left(20-22^{\circ} \mathrm{C}\right)$ until fed.

\section{Experimental Fish and Feeding Trial}

Rainbow trout fingerlings were hatched from eggs obtained from a global aquaculture supplier. Rainbow trout juveniles (initial body weight: $18.5 \pm 0.3 \mathrm{~g}$ ) were randomly stocked into each of nine, 145-L tanks at 40 fish per tank. Constant temperature spring water $\left(15^{\circ} \mathrm{C}\right)$ was supplied at $8-10 \mathrm{~L} \min ^{-1}$ to each experimental tank. Each diet was assigned randomly to three tanks in a completely randomized design. Fish were hand-fed to apparent satiation three times per day, 6 days per week for 24 weeks. Photoperiod was maintained at $14 \mathrm{~h}$ light: $10 \mathrm{~h}$ dark with fluorescent lights controlled by electric timers. At week 18, one of the tanks from Diet 2 was removed from the study due to a valve failure resulting in a period of no incoming water flow overnight followed by poor fish performance and symptoms consistent with bacterial gill disease, reducing this treatment to two replicate tanks. After 24 weeks, all fish were moved to an outdoor facility and stocked into each of eight, 1,300-L tanks for another 28 weeks 
(52 weeks total) under natural light from the $10^{\text {th }}$ January 2020 to the $29^{\text {th }}$ July 2020.

\section{Sample Collection and Proximate Analysis}

At the end of 52 weeks, 24-h postprandial, all the fish were counted and weighed to calculate weight gain (WG), specific growth rate (SGR), feed conversion ratio (FCR) and survival. After the final weighing, three fish per tank were anesthetized with tricaine methanesulfonate (MS-222, $100 \mathrm{mg} \mathrm{L}^{-1}$, buffered to $\mathrm{pH}$ 7.0). Then, individual body weight and length of fish was measured, and condition factor (CF) was calculated. Wholeblood was collected from the caudal vasculature of fish identified above with $1-\mathrm{ml}$ heparinized syringes fitted with a $24 \mathrm{G} 1.5-$ inch needle and centrifuged at $1000 \mathrm{x} \mathrm{G}$ for $10 \mathrm{~min}$ to collect plasma for antioxidant enzyme activity and non-specific immune parameters. Upon euthanizing those fish with additional MS222, liver and viscera from the same fish used for plasma collection were dissected for gene expression, fatty acid analysis, and proximate analysis and weighed individually to calculate hepatosomatic index (HSI) and viscerosomatic index (VSI). From the same fish, liver and distal intestine were excised for histology. Another three fish per tank were euthanized for whole body proximate analysis. Tissue samples were snap-frozen in liquid nitrogen and stored at $-80^{\circ} \mathrm{C}$ until analysis.

Experimental feeds, liver, muscle, and whole-body fish samples were analyzed for proximate composition and energy content. Fish samples were pooled by tank and homogenized using an industrial food processor. Samples were dried in a convection oven at $105^{\circ} \mathrm{C}$ for $12 \mathrm{~h}$ to determine moisture level according to AOAC (Association of Official Analytical Chemists) (2000). Dried samples were finely ground by mortar and pestle and analyzed for $\mathrm{CP}$ (total nitrogen $\times 6.25$ ) using combustion method with a nitrogen determinator (Elementar nitrogen analyzer, Ronkonkoma, NY). Crude lipid was analyzed by subjecting samples to acid hydrolysis using an ANKOM HCL (ANKOM Technology, Macedon, NY) and extracting them with petroleum ether using an ANKOM XT15 extractor. Ash was analyzed by incineration at $550^{\circ} \mathrm{C}$ in a muffle furnace for $5 \mathrm{~h}$. The energy content of samples was determined using an isoperibol bomb calorimeter (Parr 6300, Parr Instrument Company Inc., Moline, IL).

The fatty acid composition of the liver and filet samples were determined in line with the modified AOAC method 991.39 (24). Briefly, samples were dried for 5-6h under an $\mathrm{N}_{2}$ stream at $50{ }^{\circ} \mathrm{C}$ (OA-SYS heating system, Organomation Associates, Inc., Berlin, MA, USA). Thereafter, $2 \mathrm{~mL}$ of $0.5 \mathrm{~N} \mathrm{NaOH}$ was added for sample saponification at $70^{\circ} \mathrm{C}$ for $60 \mathrm{~min}$. Following sample cooling, the free fatty acids were methylated by the addition of $2 \mathrm{~mL} 14 \% \mathrm{BF} 3$ (Boron trifluoride) in methanol and incubated at $70^{\circ} \mathrm{C}$ for $60 \mathrm{~min}$. After the samples were allowed to cool, $2 \mathrm{~mL}$ of hexane was added, inverted repeatedly for $60 \mathrm{~s}$, and $1 \mathrm{~mL}$ of saturated $\mathrm{NaCl}$ was added. The samples were again inverted repeatedly for $60 \mathrm{~s}$ and then centrifuged at $2000 \times \mathrm{G}$ for $5 \mathrm{~min}$. An aliquot $(100 \mu \mathrm{L})$ of the clarified hexane extract was diluted in hexane (1:10) and put into autosampler vials for gas chromatography/mass spectroscopy (GC/MS) analysis. The injection mode with a helium flow rate and the column temperature was as described by Overturf et al. (2013). All the analyses were done in duplicate. Filet results are provided as $\mathrm{mg}$ $100 \mathrm{~g}^{-1}$, assuming a $100 \mathrm{~g}$ portion size for human consumption.

\section{Antioxidant and Non-specific Immune Assays}

Oxidative radical production by phagocytes during respiratory burst was measured through nitro blue tetrazolium (NBT) assay described by Anderson and Siwicki (1995). Briefly, plasma and NBT (0.2\%) (Sigma-Aldrich, St. Louis, MO, USA) were mixed in equal proportion (1:1) and incubated for $30 \mathrm{~min}$ at room temperature. Then $50 \mu \mathrm{L}$ was taken out and dispensed into glass tubes. One milliliter of dimethylformamide (Sigma-Aldrich) was added and centrifuged at $2000 \times \mathrm{G}$ for $5 \mathrm{~min}$. Finally, the optical density of supernatant was measured at $540 \mathrm{~nm}$ using a microplate reader (Infinite ${ }^{\circledR}$ m200 PRO, Tecan Trading AG, Switzerland). Dimethylformamide was used as the blank.

Commercially available kits (Cayman Chemical, Ann Arbor, Michigan) were used to measure superoxide dismutase (SOD) (Item no: 706002) and catalase (CAT) (Item no: 707002) activities at $25^{\circ} \mathrm{C}$. SOD activity was determined at $450 \mathrm{~nm}$ based on xanthine and xanthine oxidase to produce superoxide radicals. SOD activity was measured based on the inhibition rate of this reaction. One unit of SOD activity is equal to $50 \%$ inhibition of decrease in 2-(4-iodophenyl)-3-(4nitrophenole)5-phenyltetrazolium chloride according to the experimental conditions. CAT activity was measured by determining the decrease in absorbance of $\mathrm{H}_{2} \mathrm{O}_{2}$ at $540 \mathrm{~nm}$. The reaction mixture containing $50 \mathrm{mM} \mathrm{K}$-phosphate buffer (pH 6.5) and $50 \mathrm{mM}$ $\mathrm{H}_{2} \mathrm{O}_{2}$ was diluted in $80 \mathrm{mM}$ K-phosphate buffer ( $\mathrm{pH} 6.5$ ). Calculation of activity was done by determining the extinction coefficient for $\mathrm{H}_{2} \mathrm{O}_{2}\left(\mathrm{a}=40 \mathrm{M}^{-1} \mathrm{~cm}^{-1}\right)$.

Lysozyme activity in plasma was analyzed with a lysozyme assay kit (Sigma-Aldrich). Micrococcus lysodeikticus $(0.75 \mathrm{mg}$ $\mathrm{mL}^{-1}$ ) was suspended in phosphate buffer $(0.1 \mathrm{M}, \mathrm{pH} 6.24)$, $800 \mathrm{uL}$ of suspension was placed in each well of 48-well plates, and $30 \mu \mathrm{L}$ plasma was added subsequently. The reduction in absorbance of the samples was recorded at $450 \mathrm{~nm}$ after incubation at room temperature for 0 and $30 \mathrm{~min}$ in a microplate reader (Infinite ${ }^{\circledR}$ m200 PRO, Tecan Trading AG, Switzerland). A reduction in absorbance of $0.001 \mathrm{~min}^{-1}$ was regarded as one unit of lysozyme activity.

\section{Histological Analysis}

Tissue samples, about $1 \mathrm{~cm}$ in length, from anterior section of the distal intestine and liver were fixed in 10\% neutral buffered formalin. All samples were processed by increasing dehydration step, cleared in xylene and embedded in paraffin wax, according to the standard procedures. Longitudinal sections were cut at $5 \mu \mathrm{m}$ thickness and stained with haematoxylin and eosin (H\&E). Examination for any pathological alterations was performed using a light microscope at different magnifications. For the evaluation of the effects of the experimental diets on the microscopic anatomy of the liver and intestine, a ranking system was employed, based on the criteria presented in Supplementary Table S1. 
TABLE 3 | Primers sequences used in real-time qPCR for the determination of gene expression.

\begin{tabular}{|c|c|c|c|c|}
\hline Genes & Forward & Reverse & Bases & Gene accession no \\
\hline elovl2 & GATGCCTGCTCTTCCAGTTC & CATTGGTGGAGACAGTGTGG & 20 & KM244737 \\
\hline elovl5 & CTATGGGCTCTC TGCTGTCC & TATCGTCTGGGA CATGGTCA & 20 & AY605100 \\
\hline$\Delta 5 \mathrm{fad}$ & GCAGAGAGAACCGAGGATGG & GCAGTGCTTCTG GACCTCTT & 20 & JD087459 \\
\hline$\Delta 6 \mathrm{fad}$ & ACCTAGTGGCTCCTCTGGTC & CAGATCCССTGACTTCTTCA & 20 & AF301910 \\
\hline $\operatorname{acox}$ & TTCCACGACCAGACCCATGA & AACGGCGTCCACCAAAGCTA & 20 & BX085367 \\
\hline
\end{tabular}

\section{RNA Extraction and Quantitative PCR}

Total RNA was isolated from each tissue using TRIzol reagent (Invitrogen, Carlsbad, CA) extraction method following the manufacturer's suggested protocol. Purity and quantity of extracted RNA were assessed by Nanodrop ND-1000 spectrophotometer (260/230 and 260/280 ratios >1.8).

Extracted RNA was treated with DNAse, then $1 \mu \mathrm{g}$ of total RNA was reverse transcribed using the iScript ${ }^{\mathrm{TM}} \mathrm{cDNA}$ Synthesis kit (BioRad, Hercules, CA). Real-time quantitative PCR was carried out on a CFX96 Real-Time System (BioRad) in 10 $\mu \mathrm{L}$ total volume reactions using iTaq SYBR Green Supermix (BioRad) and 300 ( $\Delta 6 \mathrm{fad}$ and elovl2) or $500 \mathrm{nmol}(\Delta 5 \mathrm{fad}$, elovl5, acox, gapdh and arp) primers according to the protocol provided by the manufacturer. PCR cycling conditions for all genes were as follows: $95^{\circ} \mathrm{C}$ for $5 \mathrm{~s}$ followed by $55^{\circ} \mathrm{C}$ for $30 \mathrm{~s}$ over 40 cycles with an initial denaturation step of $95^{\circ} \mathrm{C}$ for $3 \mathrm{~min}$. For each fish, PCR reactions were run in duplicate. Relative expression values for genes constituting the fatty acid oxidation, desaturation and elongation, including delta-5 fatty acyl desaturase $(\Delta 5 \mathrm{fad})$, delta-6 fatty acyl desaturase $(\Delta 6 \mathrm{fad})$, fatty acid elongase 2 (elovl2), fatty acid elongase 5 (elovl5) and acyl-Coa oxidase (acox) were determined using primers designed from rainbow trout sequences in the NCBI database. Primer sequences for genes are given in Table 3. Two genes (gapdh and $\operatorname{arp}$ ) were tested as internal reference genes, though only arp proved stable across experimental factors and was therefore chosen as the reference gene for normalization of target gene expression in both tissues. Primer PCR efficiency was calculated for each primer set using a six-step serial dilution of a pooled sample (pooled from each experimental sample for a given tissue). Data were analyzed using the relative quantification method, including efficiency correction following the method of Pfaffl (2001).

\section{Calculation and Statistical Method}

Using the live-weight and feed consumption data, the following indices were calculated.

Weight gain (WG, g/fish) $=$ (g mean final weight-g mean initial weight).

Specific growth rate $(\mathrm{SGR}, \% / \mathrm{d})=[(\mathrm{Ln}$ mean final weight-Ln mean initial weight)/number of days] $\times 100$.

Survival $(\%)=$ (number of fish at the end of the trial/number of fish at the beginning) $\times 100$.
TABLE 4 | Growth performance and feed utilization of rainbow trout fed for 52 weeks*.

\begin{tabular}{|c|c|c|c|}
\hline \multirow[t]{2}{*}{ Ingredients (\%) } & \multicolumn{3}{|c|}{ Diets } \\
\hline & LO-O & LO-8 & LO-16 \\
\hline Initial weight (g) & $18.5 \pm 0.09$ & $18.5 \pm 0.08$ & $18.5 \pm 0.08$ \\
\hline Final weight (g) & $869 \pm 18.6^{b}$ & $967 \pm 36.4^{a}$ & $955 \pm 10.8^{a}$ \\
\hline Weight gain $\left(\mathrm{g} \mathrm{fish}^{-1}\right)$ & $850 \pm 18.5^{b}$ & $949 \pm 36.4^{a}$ & $937 \pm 10.8^{a}$ \\
\hline SGR & $1.07 \pm 0.10^{b}$ & $1.10 \pm 0.01^{\mathrm{a}}$ & $1.10 \pm 0.00^{a}$ \\
\hline Feed intake $\left(\mathrm{g} \mathrm{fish}^{-1}\right)$ & $1,076 \pm 12.1$ & $1,219 \pm 65.5$ & $1,244 \pm 73.5$ \\
\hline $\mathrm{FCR}^{\mathrm{b}}$ & $1.27 \pm 0.04$ & $1.28 \pm 0.02$ & $1.32 \pm 0.07$ \\
\hline Survival rate (\%) & $83.8 \pm 2.21$ & $83.8 \pm 2.70$ & $74.8 \pm 4.59$ \\
\hline Condition factor (\%) & $1.19 \pm 0.08$ & $1.22 \pm 0.06$ & $1.22 \pm 0.03$ \\
\hline $\mathrm{HSI}^{\mathrm{C}}$ & $0.84 \pm 0.07$ & $0.88 \pm 0.00$ & $0.74 \pm 0.05$ \\
\hline$V S I^{d}$ & $9.07 \pm 0.78$ & $8.90 \pm 0.27$ & $9.09 \pm 0.90$ \\
\hline
\end{tabular}

Mean $\pm S E$ ( $n=3$ tanks per treatment) except for diet $2(n=2)$ in the same row that share the same superscript are not statistically different $(P>0.05)$. ${ }^{2} S G R$, specific growth rate $(\%$ day $^{-1}$ ). ${ }^{b} \mathrm{FCR}$, feed conversion ratio. ${ }^{c} \mathrm{HSI}$, hepatosomatic index (\%). ${ }^{d} \mathrm{VSI}$, viscerosomatic index (\%).

Average feed intake (FI, g/fish) $=\mathrm{g}$ total dry feed intake/number of surviving fish.

Feed conversion ratio $(\mathrm{FCR})=\mathrm{g}$ total feed consumed $/(\mathrm{g}$ final biomass $-\mathrm{g}$ initial biomass $+\mathrm{g}$ dead fish weight).

Condition factor $(\mathrm{CF})=(\mathrm{g}$ body weight $) /(\mathrm{cm} \text { body length })^{3}$ $\times 100$.

Hepatosomatic index $(\mathrm{HSI})=(\mathrm{g}$ liver weight $) /(\mathrm{g}$ whole body weight) $\times 100$.

Viscerosomatic index $(\mathrm{VSI})=(\mathrm{g}$ visceral weight $) /(\mathrm{g}$ whole body weight) $\times 100$.

$\mathrm{ADC}$ diet $=1-[(\mathrm{F} / \mathrm{D}) \times(\mathrm{Di} / \mathrm{Fi})]-$ where $\mathrm{D}=\%$ lipid of diet, $\mathrm{F}=\%$ lipid of feces, $\mathrm{Di}=\%$ digestion indicator of diet, $\mathrm{Fi}=\%$ digestion indicator of feces.

$\mathrm{ADC}$ ingredient $=\mathrm{ADCT}+[((1-\mathrm{s}) \mathrm{DR}) / \mathrm{s} \mathrm{DI}] \times(\mathrm{ADCT}$ - ADCR), where ADCT $=\mathrm{ADC}$ of test diet, $\mathrm{ADCR}=\mathrm{ADC}$ of reference diet, $\mathrm{DR}=\%$ lipid of reference diet, $\mathrm{DI}=\%$ lipid of test ingredient, $s=$ proportion of test ingredient in test diet $(0.2)$.

Tank mean values ( $n=3$; except diet $2, n=2)$ were used for statistical analysis. Fish growth and feed utilization indices, physiological parameters, and gene expression data were tested for normality and homogeneity of variance prior to one-way Analysis of Variance (ANOVA). If significant 


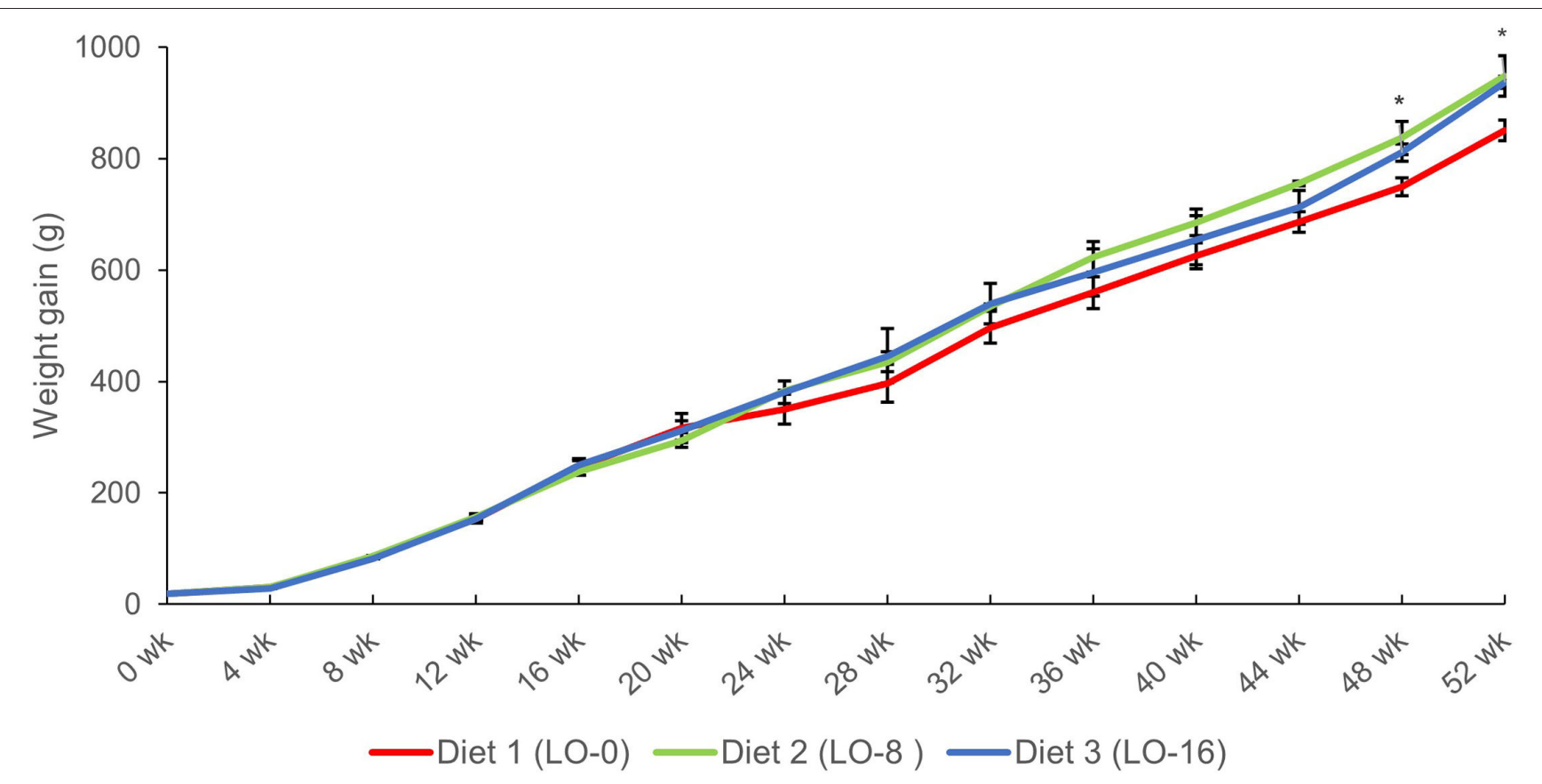

FIGURE 1 | Mean body weight over time of rainbow trout fed experimental diets differing in oil source for 52 weeks. ${ }^{\star} P<0.05$.

differences were found, data were subjected to Tukey's HSD test to separate the means at a significance level of $P<0.05$. SPSS (Version 21 for Window; IBM SPSS Inc., Chicago, IL, USA) was used for all statistical analyses. Principal components analysis (PCA) was performed by dimension reduction and visual mapping of samples based on non-specific immune response parameters and filet fatty acid composition using R v4.0 (The R Foundation, Vienna, Austria). A Kruskal-Wallis test followed by Wilcoxon post-hoc analysis was used for testing of histological results because the values did not meet parametric assumptions of normality.

\section{RESULTS}

\section{Growth Performance and Feed Utilization}

The growth performance and feed utilization of the fish are presented in Table 4. The final weight, weight gain, and SGR of fish fed diet LO-8 or LO-16 were the greatest $(P<0.05)$ compared with the fish fed LO-0. The survival rate (74.8-83.8\%) and feed conversion ratio (1.27-1.32) were similar among dietary treatments groups $(P>0.05)$. Results also showed that CF, HSI and VSI were not significantly affected by dietary treatments $(P>$ $0.05)$. ADC for crude lipid of LO was $93 \% \pm 0.2$. Changes in the mean body weight of three groups during 52 weeks of feeding is presented in Figure 1. Growth rate began to separate at 24 weeks and became significantly different after 48 weeks.

\section{Whole-Body, Liver and Filet Proximate Composition}

Whole-body, liver and filet proximate composition of rainbow trout juveniles fed the experimental diets are presented in
Table 5. There were no consistent dietary effects for percent crude protein, crude fat, or gross energy across tissues. Additionally, no significant differences in whole-body, liver, and filet proximate composition and gross energy were detected among treatment groups.

\section{Antioxidant and Non-specific Immune Responses}

Results of the non-specific plasma immune assays are presented in Table 6. Phagocytic oxidative radical production (NBT activity) in plasma of fish fed diet LO-16 was significantly higher than fish fed the other two diets $(P<0.05)$. Plasma SOD, CAT and lysozyme activities were higher for rainbow trout fed diet LO-16, but they were not statistically different $(P>0.05)$.

\section{Histological Examination}

The results of the histological evaluation from the final sampling are presented in Table 7. With regard to distal intestine tissue, it is interesting to note that both inflammation and size and number of absorptive vacuoles showed significant differences among diets. Distal intestine of fish fed diet LO-16 (Diet 3) showed a reduction in size and number of absorptive vacuoles and signs of inflammation, whereas there was no significant difference in liver histological evaluation. PCA of histology and plasma assay results together showed clear separation of dietary treatment groups, with eigenvectors indicating plasma assays were tightly correlated with one another, yet liver and intestinal histology showed opposing patterns of variance across diets (Figure 2A). 
TABLE 5 | Whole-body, liver and filet proximate composition and gross energy (wet basis) of rainbow trout fed experimental diets for 52 weeks ${ }^{*}$.

\begin{tabular}{lccc}
\hline & \multicolumn{3}{c}{ Diets } \\
\cline { 2 - 3 } & LO-0 & LO-8 & LO-16 \\
\hline Whole-body & & & \\
Dry matter (\%) & $29.3 \pm 3.15$ & $33.3 \pm 0.68$ & $28.8 \pm 1.06$ \\
Crude protein (\%) & $17.5 \pm 1.09$ & $18.2 \pm 0.58$ & $18.0 \pm 0.64$ \\
Crude fat (\%) & $9.40 \pm 2.45$ & $12.8 \pm 1.28$ & $8.80 \pm 1.45$ \\
Ash (\%) & $2.1 \pm 0.31$ & $1.7 \pm 0.34$ & $2.3 \pm 0.26$ \\
Gross energy (MJ kg-1) & $26.8 \pm 0.84$ & $28.2 \pm 0.84$ & $26.7 \pm 0.78$ \\
Liver & & & \\
Dry matter (\%) & $14.7 \pm 1.05$ & $15.2 \pm 0.93$ & $13.2 \pm 0.75$ \\
Crude protein (\%) & $9.63 \pm 0.27$ & $9.67 \pm 0.63$ & $8.81 \pm 0.52$ \\
Crude fat (\%) & $0.83 \pm 0.21$ & $0.64 \pm 0.12$ & $0.47 \pm 0.02$ \\
Gross energy (MJ kg-1) & $22.0 \pm 0.17$ & $22.1 \pm 0.03$ & $22.0 \pm 0.07$ \\
Filet & & & \\
Dry matter (\%) & $21.6 \pm 0.67$ & $20.3 \pm 0.04$ & $21.3 \pm 1.16$ \\
Crude protein (\%) & $16.0 \pm 0.81$ & $14.8 \pm 0.18$ & $15.7 \pm 0.47$ \\
Crude fat (\%) & $4.95 \pm 0.12$ & $4.48 \pm 0.28$ & $5.00 \pm 0.41$ \\
Gross energy (MJ kg-1) & $26.2 \pm 0.13$ & $25.8 \pm 0.26$ & $26.0 \pm 0.19$ \\
\hline
\end{tabular}

"Mean $\pm S E$ ( $n=3$ tanks per treatment) except for diet $2(n=2)$ in the same row that share the same superscript are not statistically different $(P>0.05)$.

TABLE 6 | Non-specific immune responses of rainbow trout fed experimental diets for 52 weeks*.

\begin{tabular}{lccc}
\hline & \multicolumn{3}{c}{ Diets } \\
\cline { 2 - 4 } & LO-0 & LO-8 & LO-16 \\
\hline NBT $^{\mathrm{a}}$ & $0.28 \pm 0.12^{\mathrm{b}}$ & $0.19 \pm 0.01^{\mathrm{b}}$ & $0.90 \pm 0.14^{\mathrm{a}}$ \\
SOD $^{\mathrm{b}}$ & $6.75 \pm 0.28$ & $6.40 \pm 0.59$ & $7.41 \pm 0.63$ \\
Catalase $^{\mathrm{c}}$ & $42.0 \pm 2.31$ & $46.6 \pm 0.55$ & $48.1 \pm 2.52$ \\
Lysozyme $^{\mathrm{d}}$ & $329 \pm 7.22$ & $385 \pm 24.7$ & $414 \pm 40.2$
\end{tabular}

"Mean $\pm S E$ ( $n=3$ tanks per treatment) except for diet $2(n=2)$ in the same row that share the same superscript are not statistically different $(P>0.05)$. ${ }^{a} N B T$, Nitro-blue tetrazolium assay (OD $540 \mathrm{~nm}) .{ }^{b} \mathrm{SOD}$, Super oxide dismutase (\%inhibition). 'Catalase, Catalase activity ( $\mathrm{nmol} \mathrm{min}^{-1} \mathrm{ml}^{-1}$ ). ${ }^{d}$ Lysozyme, Lysozyme activity (Unit $\mathrm{mL}^{-1}$ enzyme).

\section{Fatty Acid Composition of Filet}

Filet fatty acid composition of rainbow trout juveniles fed the experimental diets are presented in Table 8. Linoleic acid (C18:2n-6) of fish filet of fish fed diet LO-16 (795 mg $100 \mathrm{~g}^{-1}$ ) was significantly higher than those of fish fed diet LO-8 $(648 \mathrm{mg}$ $\left.100 \mathrm{~g}^{-1}\right)(P<0.05)$. ALA, ARA, EPA and DPA content was significantly higher in LO-16 diet group compared to other groups $(P<0.05)$. The filet DHA content of fish fed diet LO-8 was numerically higher than those of fish fed other two diets $(P>$ 0.05). EPA + DHA contents tended to increase as Latitude ${ }^{\mathrm{TM}}$ oil inclusion level increased to 8 and $16 \%$, but were not statistically different $(P>0.05)$. The overall filet fatty acid profile differed as a whole across dietary treatment according to PCA (Figure 2B), with the DHA eigenvector explaining separation of the LO-8
TABLE 7 | Histological scoring of rainbow trout distal intestine and liver tissue following different dietary treatments fed for 52 weeks*.

\begin{tabular}{lccc}
\hline & $\begin{array}{c}\text { Diet 1 } \\
\text { Lo-0 }\end{array}$ & $\begin{array}{c}\text { Diet 2 } \\
\text { LO-8 }\end{array}$ & $\begin{array}{c}\text { Diet 3 } \\
\text { LO-16 }\end{array}$ \\
\hline $\begin{array}{l}\text { Distal intestine } \\
\text { Inflammation }\end{array}$ & & & \\
Absorptive vacuoles & $2.89 \pm 0.87^{\mathrm{a}}$ & $2.00 \pm 0.00^{\mathrm{b}}$ & $3.33 \pm 0.47^{\mathrm{a}}$ \\
Liver & & & \\
Glycogen vacuolation & $2.11 \pm 0.92^{\mathrm{ab}}$ & $1.67 \pm 0.75^{\mathrm{b}}$ & $3.22 \pm 0.42^{\mathrm{a}}$ \\
$\begin{array}{l}\text { Perivascular inflammation } \\
\text { Focal inflammation }\end{array}$ & $1.67 \pm 0.67$ & $2.83 \pm 0.37$ & $2.11 \pm 0.57$ \\
Nuclear vacuoles & $1.33 \pm 0.67$ & $1.17 \pm 0.37$ & $1.33 \pm 0.67$ \\
\hline & $1.33 \pm 0.67$ & $1.17 \pm 0.37$ & $1.11 \pm 0.0000$ \\
\hline
\end{tabular}

*Mean $\pm S E$ ( $n=9$ fish per treatment) except for diet $2(n=6)$ in the same row that share the same superscript are not statistically different $(P>0.05$; Data was analyzed by Kruskal-Wallis test and Wilcoxon's post-hoc test).

group and other n-3/n-6 LC-PUFA concentrations explaining the most variance in the LO-16 group.

\section{Gene Expression}

The relative mRNA (RT-qPCR) expression of fatty acid metabolism related genes, fatty acid elongases 2 and 5 (elovl 2 and elovl5), desaturases ( $\Delta 5 f a d$ and $\Delta 6 f a d)$ and acyl-CoA oxidase (acox) in liver and muscle of rainbow trout fed experimental diets is presented in Figures 3, 4, respectively. The hepatic gene expressions of elovl2 and elovl5 were unaffected by the diet $(P>0.05)$ (Figure 3$)$, however those genes were significantly upregulated $(P<0.05)$ in the LO-16 group compared to LO0 group in muscle (Figure 4). The fish fed LO-8 or LO-16 diet showed a significantly higher expression of $\Delta 6 f a d$ as well as acox in both liver and muscle compared to the fish fed LO-0 diet, while the relative mRNA expression of $\Delta 5 f a d$ was not significantly different among the dietary treatment group $(P>0.05)$.

\section{DISCUSSION}

\section{Growth Performance and Feed Utilization}

This study is the first to address the impact of the substitution of FO by transgenic canola oil, up to $100 \%$ substitution, on rainbow trout performance, health, and n-3 LC-PUFA tissue composition over a complete production cycle, from fingerling to the marketing size (52 weeks). In the present study, EPA+DHA contents (\% of the diet) were formulated to be $3 \%$. Results were promising, demonstrating that both inclusion levels of $\mathrm{LO}(8$ and $16 \%)$ proved to be effective. Remarkably, the fish fed diet LO8 and LO-16 showed significantly increased growth performance and filet EPA + DHA concentrations, similar to those achieved in fish fed diet LO-0. While unexpected, the growth results suggest improved lipid utilization in fish fed the diets containing LO compared to fish in the LO-0 diet group. It is worth noting that growth rates began to separate among treatments at 24 weeks and became significantly different after 48 weeks (Figure 1), supporting the need for long-term studies. It is known that the feeding duration in dietary studies can lead to significant 


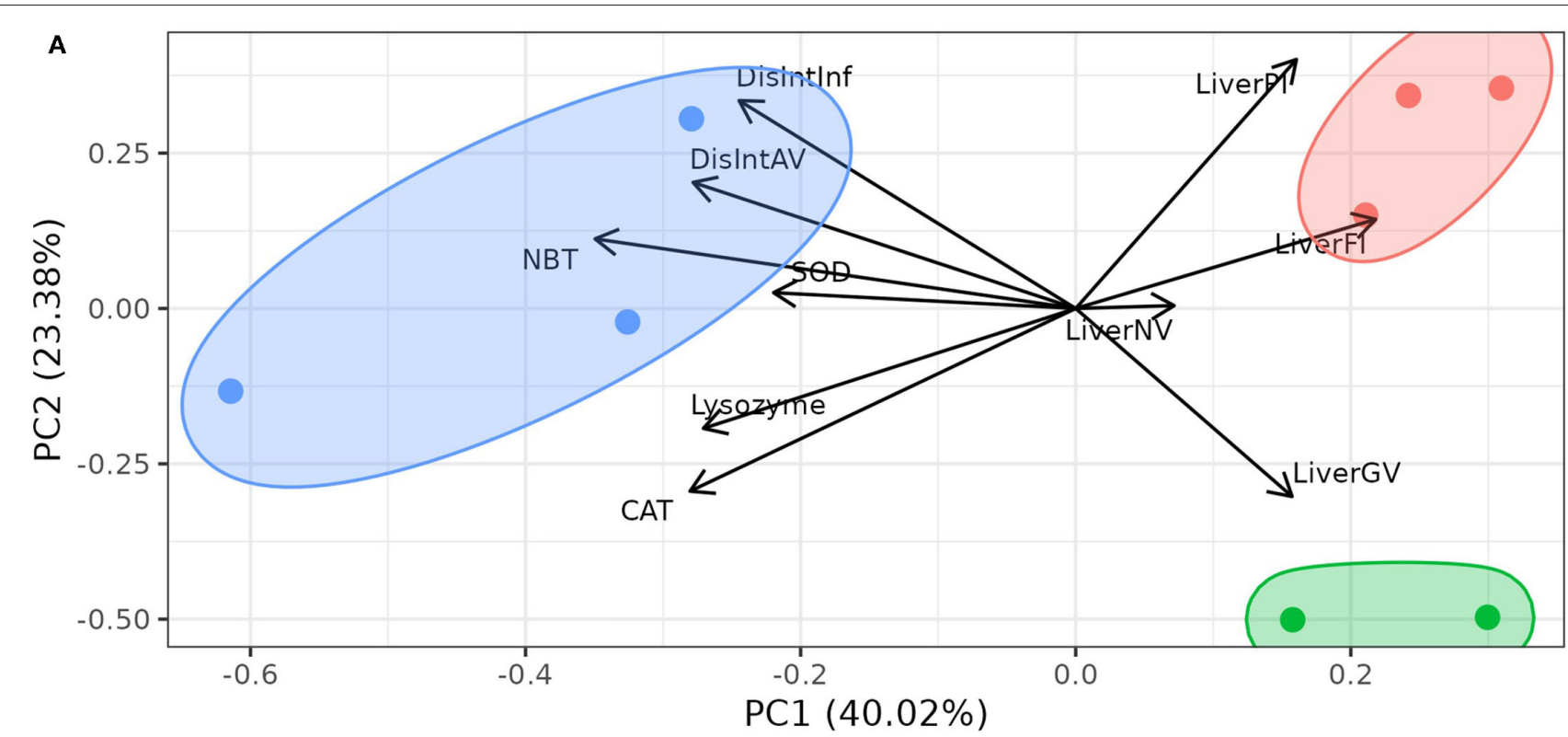

B

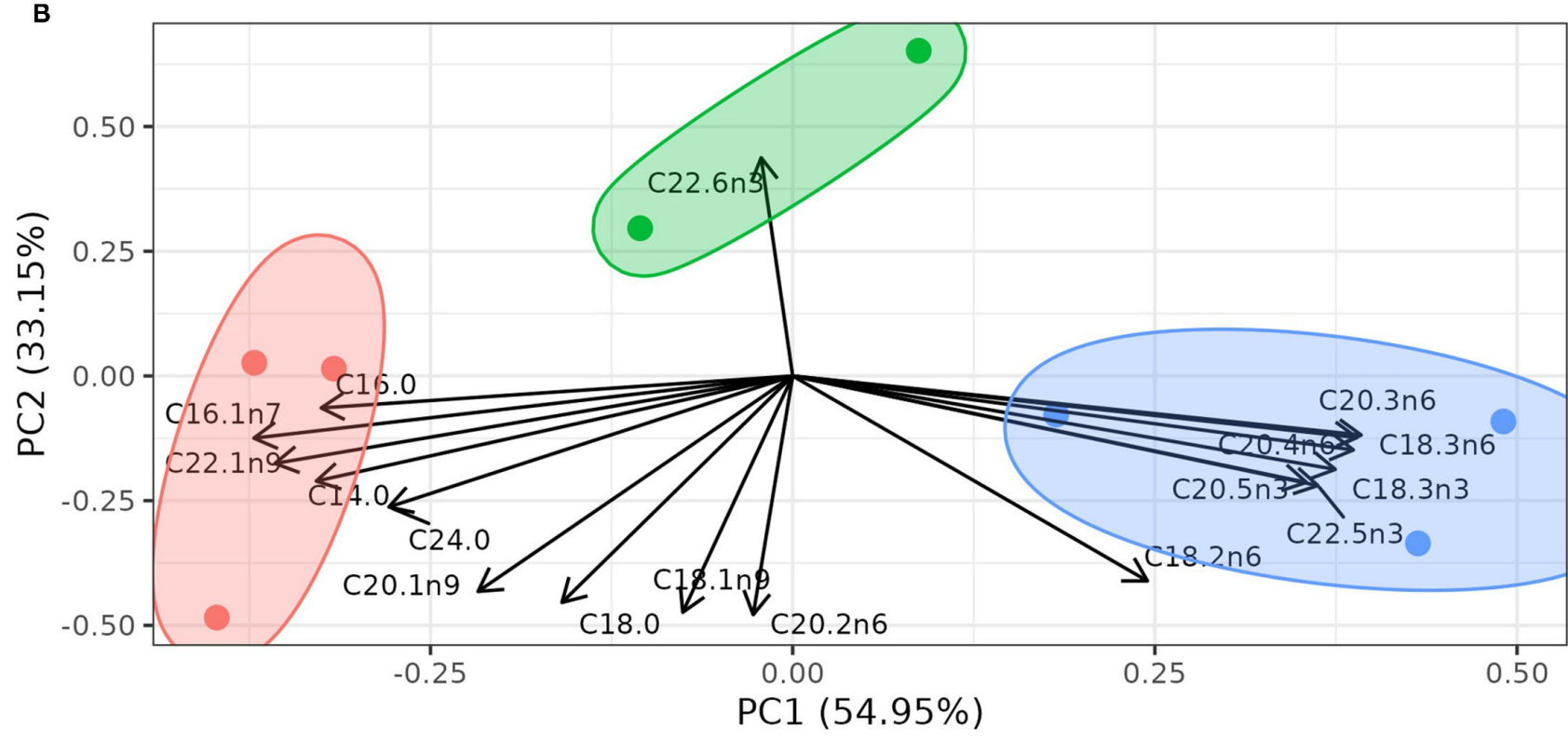

\section{Diet $\mathrm{LO}-0$ LO-8 0 LO-16}

FIGURE 2 | Principal component analysis (PCA) of the non-specific immune response parameters (A) and the filet fatty acid composition (B) of rainbow trout fed experimental diets for 52 weeks. NBT, nitro-blue tetrazolium; SOD, superoxide dismutase; CAT, catalase; DisInt AV, distal intestine absorptive vacuoles; Dislnt Inf, distal intestine inflammation; Liver PI, liver perivascular inflammation; Liver FI, liver focal inflammation; Liver NV, liver nuclear vacuoles; Liver GV, liver glycogen vacuolation.

growth differences, and it is not easy to compare directly with results from the experiments of shorter duration (Weatherup and McCracken, 1999; De Francesco et al., 2004).

One possible reason for improved growth (final weight, WG, SGR) of fish fed the LO-8 and LO-16 diets could be related to the higher ARA content in LO. Recently, the importance of n-6 LC-PUFA, particularly ARA, has been highlighted (Bell and Sargent, 2003; Norambuena et al., 2015; Xu et al., 2017;
Torrecillas et al., 2018; Araújo et al., 2019). Some studies have shown that ARA plays crucial roles in marine fish growth and survival (Xu et al., 2010; Yuan et al., 2015; Rombenso et al., 2016; Torrecillas et al., 2018), reproduction (Bromage et al., 2001; Kowalska and Kowalski, 2014) and stress and disease resistance (Koven et al., 2001, 2003; Martins et al., 2013), hence playing a vital role across the entirety of the fish life cycle. On the contrary, other studies have demonstrated that the inclusion of dietary 
TABLE 8 | Filet fatty acid composition of rainbow trout juvenile fed experimental diets for 52 weeks*.

\begin{tabular}{|c|c|c|c|c|c|c|}
\hline \multirow[b]{2}{*}{ Fatty acids } & \multicolumn{6}{|c|}{ Diet } \\
\hline & $\mathrm{mg} 100 \mathrm{~g}^{-1}$ & $\%$ FAME & $\mathrm{mg} 100 \mathrm{~g}^{-1}$ & $\%$ FAME & $\mathrm{mg} 100 \mathrm{~g}^{-1}$ & $\%$ FAME \\
\hline C14:0 & $60.3 \pm 2.17$ & $1.22 \pm 0.04$ & $46.1 \pm 13.0$ & $1.03 \pm 0.29$ & $43.8 \pm 4.79$ & $0.95 \pm 0.14$ \\
\hline C16:0 & $845 \pm 50.2^{a}$ & $17.1 \pm 1.01^{a}$ & $665 \pm 22.6^{b}$ & $14.8 \pm 0.50^{\mathrm{ab}}$ & $668 \pm 60.3^{\mathrm{ab}}$ & $13.4 \pm 1.21^{b}$ \\
\hline$\Sigma$ SFA & $1,200 \pm 36.3^{a}$ & $24.2 \pm 0.73^{\mathrm{a}}$ & $942 \pm 10.6^{b}$ & $21.0 \pm 0.24^{\mathrm{ab}}$ & $970 \pm 62.2^{b}$ & $19.5 \pm 1.28^{b}$ \\
\hline C16:1-7 & $246 \pm 23.6^{a}$ & $4.96 \pm 0.48^{a}$ & $208 \pm 9.04^{\mathrm{ab}}$ & $4.65 \pm 0.20^{\mathrm{ab}}$ & $179 \pm 18.5^{b}$ & $3.58 \pm 0.37^{b}$ \\
\hline C18:1n-9 & $1,297 \pm 40.5^{\mathrm{a}}$ & $26.2 \pm 0.82$ & $1,079 \pm 31.5^{b}$ & $24.1 \pm 0.70$ & $1,272 \pm 38.2^{\mathrm{a}}$ & $25.4 \pm 0.76$ \\
\hline C20:1n-9 & $92.5 \pm 12.6^{a}$ & $1.87 \pm 0.25$ & $49.1 \pm 12.7^{b}$ & $1.10 \pm 0.28$ & $68.1 \pm 3.92^{\mathrm{ab}}$ & $1.36 \pm 0.08$ \\
\hline C22:1n-9 & $24.3 \pm 5.20^{a}$ & $0.49 \pm 0.11^{\mathrm{a}}$ & $13.5 \pm 2.07^{\mathrm{ab}}$ & $0.30 \pm 0.05^{\mathrm{ab}}$ & $8.55 \pm 0.29^{b}$ & $0.17 \pm 0.01^{b}$ \\
\hline C20:4n-6 (ARA) & $51.9 \pm 7.11^{\mathrm{b}}$ & $1.05 \pm 0.14^{\mathrm{a}}$ & $66.8 \pm 2.87^{b}$ & $1.49 \pm 0.06^{\mathrm{ab}}$ & $93.3 \pm 8.32^{a}$ & $1.87 \pm 0.17^{b}$ \\
\hline n-6 PUFA & $823 \pm 40.3^{b}$ & $16.6 \pm 0.81^{b}$ & $789 \pm 18.1^{b}$ & $17.6 \pm 0.40^{\mathrm{ab}}$ & $1,027 \pm 61.1^{a}$ & $20.5 \pm 1.22^{\mathrm{a}}$ \\
\hline C18:3n-3 & $41.0 \pm 5.09^{b}$ & $0.83 \pm 0.10^{b}$ & $50.2 \pm 1.36^{b}$ & $1.12 \pm 0.03^{\mathrm{ab}}$ & $78.5 \pm 8.74^{a}$ & $1.57 \pm 0.17^{a}$ \\
\hline C20:5n-3 (EPA) & $239 \pm 4.95^{b}$ & $4.83 \pm 0.10^{b}$ & $241 \pm 7.24^{b}$ & $5.37 \pm 0.16^{b}$ & $416 \pm 14.6^{a}$ & $8.32 \pm 0.29^{a}$ \\
\hline C22:5n-3 (DPA) & $71.3 \pm 3.00^{b}$ & $1.44 \pm 0.06^{b}$ & $70.3 \pm 3.30^{b}$ & $1.57 \pm 0.07^{b}$ & $133 \pm 9.78^{a}$ & $2.66 \pm 0.20^{a}$ \\
\hline C22:6n-3 (DHA) & $840 \pm 68.8$ & $17.0 \pm 1.39^{b}$ & $934 \pm 16.3$ & $20.9 \pm 0.36^{a}$ & $825 \pm 49.2$ & $16.5 \pm 0.98^{b}$ \\
\hline $\mathrm{EPA}+\mathrm{DHA}$ & $1,079 \pm 63.9$ & $21.8 \pm 1.29^{b}$ & $1,175 \pm 23.6$ & $26.2 \pm 0.53^{a}$ & $1,241 \pm 62.5$ & $24.8 \pm 1.25^{\mathrm{ab}}$ \\
\hline n-3 PUFA & $1,191 \pm 56.3^{b}$ & $24.1 \pm 1.14^{b}$ & $1,296 \pm 21.6^{\mathrm{ab}}$ & $28.9 \pm 0.48^{\mathrm{a}}$ & $1,453 \pm 69.5^{a}$ & $29.1 \pm 1.39^{a}$ \\
\hline$n-3 / n-6$ & \multicolumn{2}{|c|}{$1.45 \pm 0.14$} & \multicolumn{2}{|c|}{$1.64 \pm 0.01$} & \multicolumn{2}{|c|}{$1.42 \pm 0.09$} \\
\hline
\end{tabular}

"Values are mean $\pm S E(n=3$ tanks per treatment) except for diet $2(n=2)$ in the same row that share the same superscript or absence of superscripts are not statistically different $(P>0.05)$.

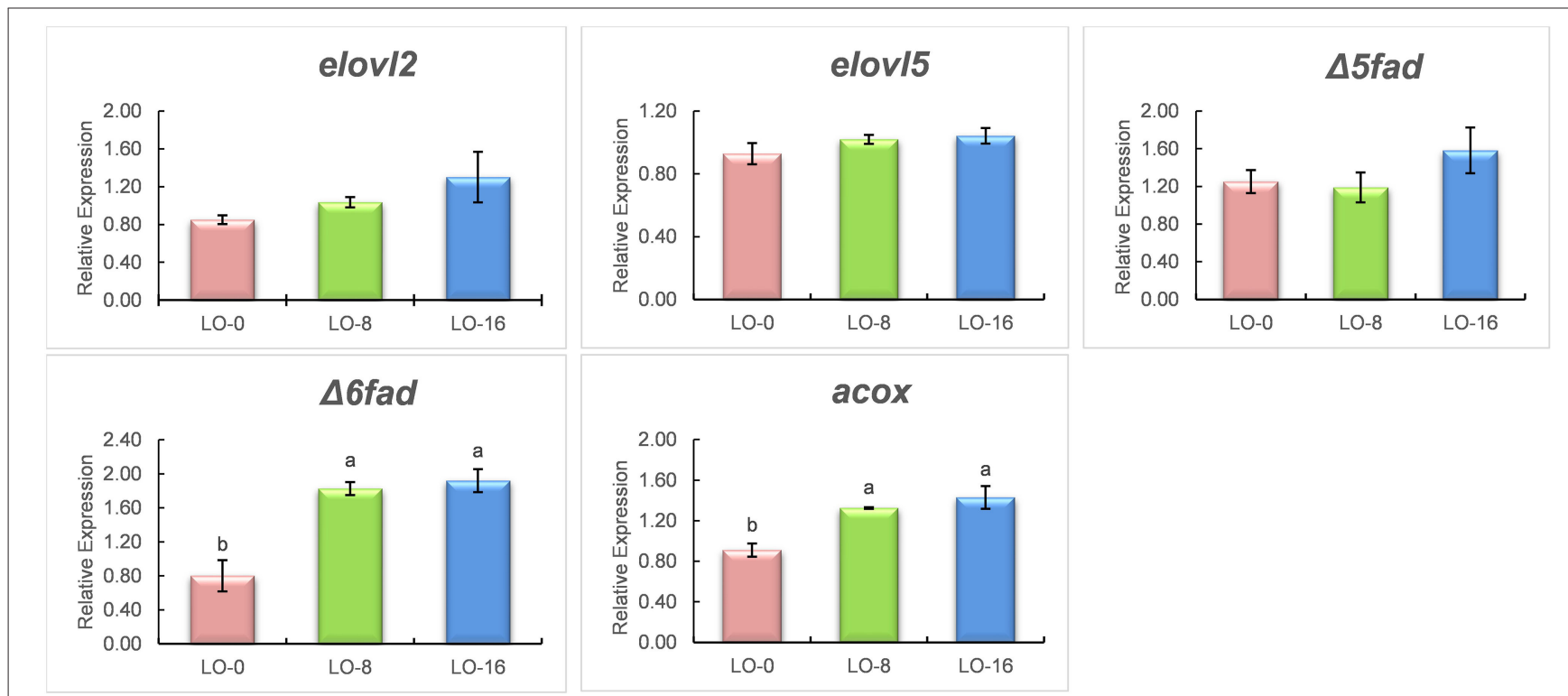

FIGURE 3 | Relative mRNA expression (normalized against arp) of genes involved in elongation (elovl2 and elovl5), desaturation ( $\Delta 5$ fad and $\Delta 6$ fad) and $\beta$-oxidation (acox) in liver of rainbow trout fed experimental diets for 52 weeks. Mean \pm SE $(n=9$ fish per treatment except diet $2, n=6)$ in the same row that share the same superscript are not statistically different $(P>0.05)$. Three fish from each tank were used for gene expression. elovl2, Elongation of very long chain fatty acids-like 2 ; elovl5, Elongation of very long chain fatty acids-like $5 ; \Delta 5 \mathrm{fad}$, Delta- 5 fatty acid desaturase; $\Delta 6 \mathrm{fad}$, Delta- 6 fatty acid desaturase. 


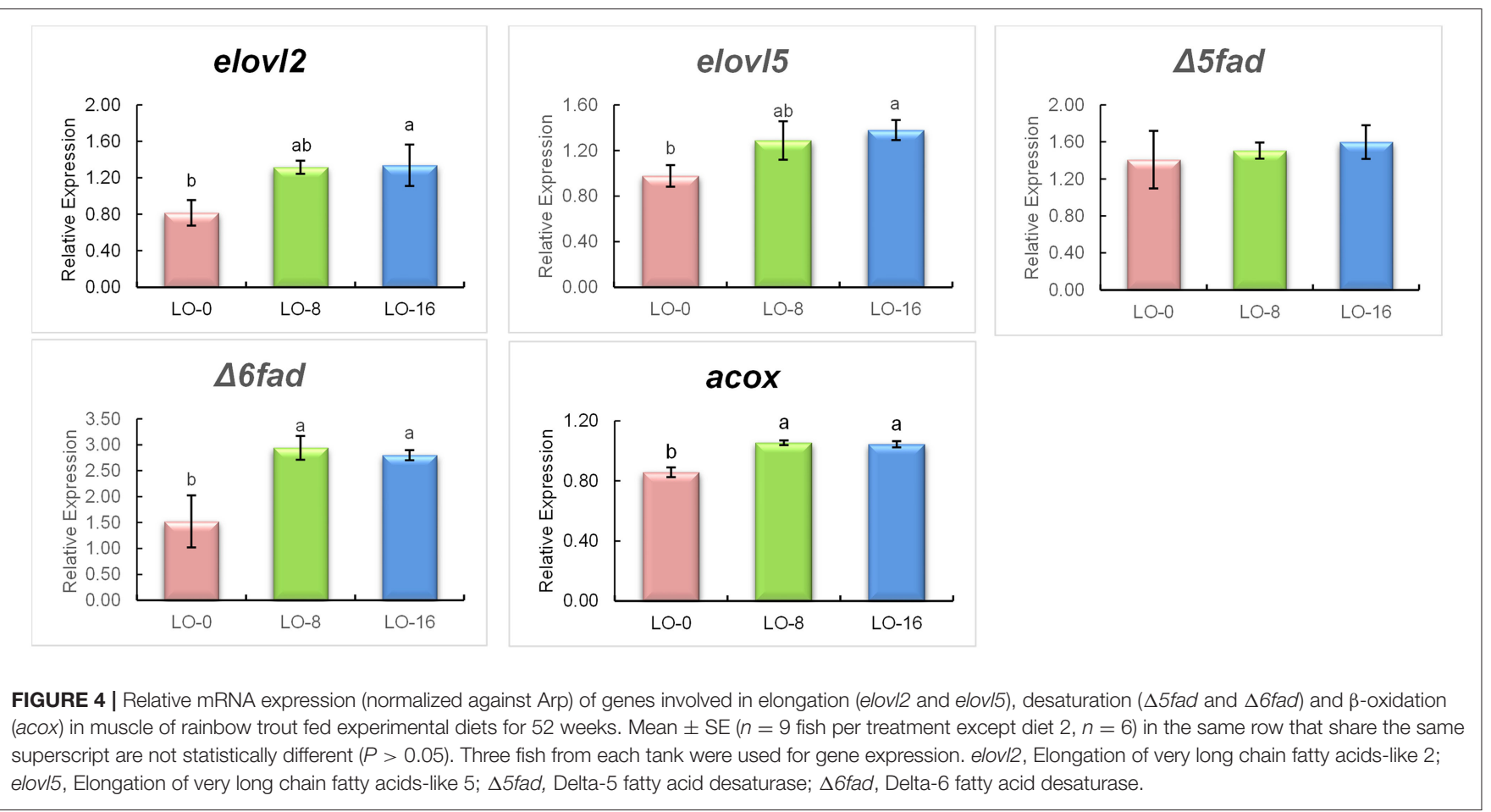

ARA did not improve fish growth performance (Koven et al., 2001; Asil et al., 2017; Chee et al., 2020). These different results may be due to distinct experimental conditions, fish size, and duration of the feeding trial. It is known that rainbow trout have a limited capacity to bioconvert ALA to DHA as well as linoleic acid to ARA, similar to many marine carnivorous fishes. Moreover, the preference of desaturase and elongase for $n-3$ over n-6 substrates leads to ARA synthesis being limited (Bell and Sargent, 2003), suggesting that ARA could be required in adult rainbow trout. Most studies have focused on the functions of ARA in juveniles, but little research has examined the influences of ARA on growth in sub-adult and adult fish.

\section{Antioxidant and Non-specific Immune Responses}

Although not observed in the current study, reports with larval fish suggest that ARA may be responsible for enhanced fish survival (Bessonart et al., 1999; Atalah et al., 2011; Yuan et al., 2015). Despite the fact that ARA may be a critical omega- 6 fatty acid for some fish species to achieve proper growth, development, and survival, other studies remind us that generation of reactive oxygen species (ROS) at high levels produced by activating NADPH-oxidase can cause toxicity through oxidative stress, as a potential result of an imbalance between antioxidant defenses and ROS generation when excessive levels of ARA are provided in diet (Cury-Boaventura and Curi, 2005; Schrader and Fahimi, 2006; Sakin et al., 2011; Chee et al., 2020). Although performance was unaffected, observations of elevated levels of plasma phagocytic oxidative radical production (NBT activity), a measurement of oxidative radical production, in the present study suggest a need for more research on ARA as a functional fatty acid in fish feeds across life stages.

Lysozyme, a non-specific innate immune molecule present in the plasma and body fluids of fish, plays a considerable role in host protection against microbial invasion (Li et al., 2021). While not significant $(P=0.075)$, higher plasma lysozyme activity in fish fed LO-16 diet are consistent with the conclusions of Chee et al. (2020), in which lysozyme activity increased with increasing dietary ARA levels. The increased lysozyme activity with increasing ARA levels could be a result of increased production of leukotriene $\mathrm{B}_{4}$, a stimulator of release of lysosomal enzymes and superoxide in neutrophils, derived from ARA (Samuelsson, 1983; Chee et al., 2020). Well-known indexes of antioxidant defense status, SOD and CAT activities, were not significantly different in the present study; however, higher activities have been reported in studies with juvenile Japanese seabass (Xu et al., 2010) and Malabar red snapper (Chee et al., 2020). Since SOD and CAT are antioxidant enzymes known to scavenge ROS, increased SOD and CAT activities in those studies were likely in response to increased ROS production associated with increased respiratory burst activity.

\section{Histological Examination}

Histological evaluation of the distal intestine of rainbow trout in the present study indicated impaired structural morphology when fed the LO-16 diet compared to fish fed the LO-8 diet but not the LO-0 diet. Specifically, fish fed the LO-0 and LO16 diets exhibited increased inflammation compared to fish fed LO-8 diet, while fish fed the LO-16 diet showed reduced size and number (higher score) of absorptive vacuoles. Again, this might be explained by the higher level of ARA. Very little has 
been reported regarding the effects of ARA on fish intestinal histology in fish. Qi et al. (2016) reported that moderate levels of dietary ARA ( $0.51 \%$ of dry matter) had positive effects on the number of goblet cells and the length of intestinal villus, whereas higher ARA levels (0.88 and $0.96 \%)$ had detrimental effects in juvenile golden pompano (Trachinotus ovatus). Yu et al. (2019) also reported that dietary ARA supplementation disrupted the intestinal physical barrier of tiger puffer, showing that the gene expression of tight junction proteins, claudin-4 and 7 and zonula occludens-1, was down-regulated in groups supplemented with ARA.

\section{Fatty Acid Composition of Filet}

An important aspect of the present study was to assess if LO influenced fatty acid metabolism, as it contains relatively high EPA and DPA levels. In the present study, muscle fatty acid profiles generally reflected those of the diets, as reported previously in other studies in fish (Montero et al., 2005; Turchini et al., 2009). Interestingly, muscle of fish fed the LO-8 diet showed lower levels of C16:0, C18:1n-9, C18:2n-6 (linoleic acid, LA) fatty acids and DPA and higher levels of DHA compared to the diet, suggesting that the decrease and low retention of these fatty acids could have occurred due to utilization as an energy source by the $\beta$-oxidation pathway and DPA being converted to DHA. It has been reported that LA, C16:0, C16:1, and C18:1n-9 fatty acids are preferred substrates for $\beta$-oxidation and energy generation in the mitochondria (Henderson, 1996; Bell et al., 2004). Drouin et al. (2019) reported that DPA supplementation affected the overall fatty acid profile, significantly increased EPA and DHA in the liver, and resulted in a slight increase of DHA in the heart and red blood cells in rats. Despite the highest level of DPA in diet LO-16, the concentrations of DHA in the filet of fish fed diet LO-16 was numerically lower than those of fish fed diet LO-8, with perhaps the high inclusion of ARA negatively affecting the conversion of EPA or DPA to DHA, as ARA, EPA and DPA compete for the same enzymes (elovl2 and elovl5) in their synthesis pathways. This is supported by relatively higher fatty acid content of EPA and DHA in the filet of fish fed diet LO-16. However, it is worth noting that the filet DHA content of fish fed diet LO-16 was not significantly different compared to the diet LO-0. In the current study, the filet EPA + DHA contents of fish fed all three experimental diets satisfied the suggested consumption recommendation by the American Heart Association for people without coronary heart disease $(500 \mathrm{mg}$ day $^{-1}$ ) and with coronary heart disease (1000 $\left.\mathrm{mg} \mathrm{day}^{-1}\right)$.

\section{Gene Expression}

The same patterns of gene expression were observed in the liver and filet. It is generally accepted that the expression of $\Delta 6 \mathrm{fad}$ is highly responsive to dietary levels of n-3 LC-PUFA, being up-regulated when fish are fed low dietary levels of n-3 LCPUFA, which leads to increased production of EPA and DHA (Thanuthong et al., 2011; Morais et al., 2012). In contrast, in the present study, fish fed diets with either $8 \%$ LO or $16 \%$ LO showed up-regulation of $\Delta 6 \mathrm{fad}$ in liver and filet, which may be associated with higher levels of DPA included in both diets compared to diet LO-0. The rate-limiting step for the LC-PUFA biosynthetic pathway in fish is controlled by $\Delta 6 \mathrm{fad}$, as it is the first enzyme involved in the bioconversion of C18 PUFA to longer and more unsaturated fatty acids, including the conversion of DPA to DHA (Sprecher, 2000). This result suggests that the expression of $\triangle 6 f a d$ is more affected by the dietary levels of DPA and DHA. Fish fed the LO-16 diet, which had higher EPA and DPA contents than the other two diets, showed up-regulation of elovl2 and elovl5 in the filet, potentially explaining the higher level of DHA in filet compared to diet. Additionally, Gregory and James (2014) found that, unlike chicken, where both elovl2 and elovl5 can elongate DPA (Gregory et al., 2013), elongation of DPA to tetracosapentaenoic acid (24:5n-3), the penultimate precursor of DHA, is limited to elovl 2 in salmonids. For peroxisomal $\beta$ oxidation, acox is regarded as the rate-limiting enzyme (Morais et al., 2007). In the present study, the expression levels of acox were up-regulated in both liver and filet with increasing levels of dietary DPA, indicating that there was active catabolism of tetracosahexaenoic acid (24:6n-3), the ultimate precursor of DHA. The up-regulated expression of acox by LO agrees with the DHA content in the filet, which may indicate that a higher level of DHA was required by rainbow trout to sustain physiological function. However, to our knowledge, information on the effects of DPA on fish growth and health performance in fish is lacking due to the high cost and limited availability of high-purity DPA for in vivo studies (Drouin et al., 2019).

\section{CONCLUSIONS}

In conclusion, results of the present study demonstrate that Latitude $^{\mathrm{TM}}$ oil is highly digestible and when fed long-term, improves fish growth, and yields elevated filet n-3 LC-PUFA content, making it a sustainable, candidate lipid source for use in rainbow trout feeds. Interestingly, there was an indication of suppressed inflammation in the distal intestine of fish fed the $8 \%$ LO inclusion, which was not observed in fish fed the $16 \%$ LO inclusion, relative to the LO-0 fed fish. Our results also suggest that the unique fatty acid profile of this oil, being high in the fatty acids ARA and DPA, may have functional properties, including but not limited to oxidative stress and LC-PUFA fatty acid synthesis, that require further investigation. Additionally, further studies are needed to refine optimal LO inclusion levels in rainbow trout and salmonid feeds and to identify the mechanisms leading to improved growth when fed to rainbow trout.

\section{DATA AVAILABILITY STATEMENT}

The original contributions presented in the study are included in the article/Supplementary Materials, further inquiries can be directed to the corresponding author/s.

\section{ETHICS STATEMENT}

The animal study was reviewed and approved by University of Idaho Animal Care and Use Committee. 


\section{AUTHOR CONTRIBUTIONS}

$\mathrm{JH}, \mathrm{DI}, \mathrm{SL}$, and BS contributed to conception and design of this work. $\mathrm{JH}$ and $\mathrm{JB}$ were involved in sample collection and data analysis. BS, KO, and DI acquired funding and provided analysis tools. $\mathrm{JH}$ wrote the manuscript. All authors contributed to interpretation of data and discussion.

\section{FUNDING}

The present study was funded by Cargill Incorporated.

\section{REFERENCES}

Anderson, D. P., and Siwicki, A. K. (1995). Basic hematology and serology for fish health programs. In: Shariff, M., Arthur, J.R., Subasinghe, R.P. (Eds.), Diseases in Asian Aquaculture II. Philippines, Fish Health Section. Asian Fisheries Society, Manila. pp. 185-202.

AOAC (Association of Official Analytical Chemists). (2000). In: Cunniff, P. (Ed.), Official Methods of Analysis of the Association of Official Analytical Chemists. 17th edition. Association of Official Analytical Chemists, Inc., Arlington, VA Chapter 4. p 46.

Aranceta, J., and Pérez-Rodrigo, C. (2012). Recommended dietary reference intakes, nutritional goals and dietary guidelines for fat and fatty acids: a systematic review. Br. J. Nutr. 107, S8-S22. doi: 10.1017/S0007114512001444

Araújo, B. C., Honji, R. M., Rombenso, A. N., de Souza, G. B., de Mello, P. H., Hilsdorf, A. W. S., et al. (2019). Influences of different arachidonic acid levels and temperature on the growth performance, fatty acid profile, liver morphology and expression of lipid genes in cobia (Rachycentron canadum) juveniles. Aquaculture. 511, 734245. doi: 10.1016/j.aquaculture.2019.734245

Asil, S. M., Kenari, A. A., Miyanji, G. R., and Van Der Kraak, G. (2017). The influence of dietary arachidonic acid on growth, reproductive performance, and fatty acid composition of ovary, egg and larvae in an anabantid model fish, Blue gourami (Trichopodus trichopterus; Pallas, 1770). Aquaculture. 476, 8-18. doi: 10.1016/j.aquaculture.2017.03.048

Atalah, E., Hernández-Cruz, C. M., Ganuza, E., Benítez-Santana, T., Ganga, R., Roo, J., et al. (2011). Importance of dietary arachidonic acid for the growth, survival and stress resistance of larval European sea bass (Dicentrarchus labrax) fed high dietary docosahexaenoic and eicosapentaenoic acids. Aquac. Res. 42, 1261-1268. doi: 10.1111/j.1365-2109.2010.02714.x

Backes, J., Anzalone, D., Hilleman, D., and Catini, J. (2016). The clinical relevance of omega-3 fatty acids in the management of hypertriglyceridemia. Lipids Health Dis. 15, 1-12. doi: 10.1186/s12944-016-0286-4

Bell, J. G., Henderson, R. J., Tocher, D. R., and Sargent, J. R. (2004). Replacement of dietary fish oil with increasing levels of linseed oil: modification of flesh fatty acid compositions in Atlantic salmon (Salmo salar) using a fish oil finishing diet. Lipids. 39, 223-232. doi: 10.1007/s11745-004-1223-5

Bell, J. G., and Sargent, J. R. (2003). Arachidonic acid in aquaculture feeds: current status and future opportunities. Aquaculture. 218, 491-499. doi: 10.1016/S0044-8486(02)00370-8

Bessonart, M., Izquierdo, M. S., Salhi, M., Hernandez-Cruz, C. M., Gonzalez, M. M., and Fernandez-Palacios, H. (1999). Effect of dietary arachidonic acid levels on growth and survival of gilthead sea bream (Sparus aurata L.) larvae. Aquaculture. 179, 265-275. doi: 10.1016/S0044-8486(99)00164-7

Betancor, M. B., Li, K., Sprague, M., Bardal, T., Sayanova, O., Usher, S., et al. (2017). An oil containing EPA and DHA from transgenic Camelina sativa to replace marine fish oil in feeds for Atlantic salmon (Salmo salar L.): Effects on intestinal transcriptome, histology, tissue fatty acid profiles and plasma biochemistry. PLoS ONE. 12, e0175415. doi: 10.1371/journal.pone.0175415

Betancor, M. B., MacEwan, A., Sprague, M., Gong, X., Montero, D., Han, L., et al. (2021). Oil from transgenic Camelina sativa as a source of EPA and DHA in

\section{ACKNOWLEDGMENTS}

We greatly acknowledge Cargill and Tyson for donating transgenic canola oil (Latitude ${ }^{\mathrm{TM}}$ ) and poultry fat, respectively, used for the study. We would also like to thank Timothy Boyle, Julianna Browning, Md. Sakhawat Hossain, Jose Ortiz, and Carol Hoffman for their excellent technical assistance in fish husbandry and sampling associated with the study.

\section{SUPPLEMENTARY MATERIAL}

The Supplementary Material for this article can be found online at: https://www.frontiersin.org/articles/10.3389/fsufs. 2022.837628/full\#supplementary-material

feed for European sea bass (Dicentrarchus labrax L.). Aquaculture. 530, 735759. doi: 10.1016/j.aquaculture.2020.735759

Bou, M., Berge, G. M., Baeverfjord, G., Sigholt, T., Østbye, T. K., and Ruyter, B. (2017). Low levels of very-long-chain n-3 PUFA in Atlantic salmon (Salmo salar) diet reduce fish robustness under challenging conditions in sea cages. J. Nutrit. Sci. 6. doi: 10.1017/jns.2017.28

Bromage, N. R., Mazorra, C., Davie, A., Alorend, E., Bruce, M. P., Bell, J. G., et al. (2001). Optimising broodstock performance: maturation, fecundity, and gamete quality. Larvi. 1,87 .

Calder, P. C. (2018). Very long-chain n-3 fatty acids and human health: fact, fiction and the future. Proc. Nutr. Soc. 77, 52-72. doi: 10.1017/S0029665117003950

Chee, W. L., Turchini, G. M., Teoh, C. Y., and Ng, W. K. (2020). Dietary arachidonic acid and the impact on growth performance, health and tissues fatty acids in Malabar red snapper (Lutjanus malabaricus) fingerlings. Aquaculture. 519, 734757. doi: 10.1016/j.aquaculture.2019.734757

Cury-Boaventura, M. F., and Curi, R. (2005). Regulation of reactive oxygen species (ROS) production by C18 fatty acids in Jurkat and Raji cells. Clin. Sci. 108, 245-253. doi: 10.1042/CS20040281

De Francesco, M., Parisi, G., Médale, F., Lupi, P., Kaushik, S. J., and Poli, B. M. (2004). Effect of long-term feeding with a plant protein mixture based diet on growth and body/fillet quality traits of large rainbow trout (Oncorhynchus mykiss). Aquaculture. 236, 413-429. doi: 10.1016/j.aquaculture.2004.01.006

Drouin, G., Catheline, D., Guillocheau, E., Gueret, P., Baudry, C., Le Ruyet, P., et al. (2019). Comparative effects of dietary n-3 docosapentaenoic acid (DPA), DHA and EPA on plasma lipid parameters, oxidative status and fatty acid tissue composition. J. Nutr. Biochem. 63, 186-196. doi: 10.1016/j.jnutbio.2018. 09.029

Dyall, S. C. (2015). Long-chain omega-3 fatty acids and the brain: a review of the independent and shared effects of EPA, DPA and DHA. Front. Aging Neurosci. 7, 52. doi: $10.3389 /$ fnagi.2015.00052

Fabris, M., Abbriano, R. M., Pernice, M., Sutherland, D. L., Commault, A. S., Hall, C. C., et al. (2020). Emerging technologies in algal biotechnology: toward the establishment of a sustainable, algae-based bioeconomy. Front. Plant Sci. 11, 279. doi: $10.3389 /$ fpls.2020.00279

Gregory, M. K., Geier, M. S., Gibson, R. A., and James, M. J. (2013). Functional characterization of the chicken fatty acid elongases. J. Nutr. 143, 12-16. doi: $10.3945 /$ jn.112.170290

Gregory, M. K., and James, M. J. (2014). Rainbow trout (Oncorhynchus mykiss) Elovl5 and Elovl2 differ in selectivity for elongation of omega-3 docosapentaenoic acid. Biochim. Biophys. Acta Molec. Cell Biol. Lipid. 1841, 1656-1660. doi: 10.1016/j.bbalip.2014.10.001

Henderson, R. J. (1996). Fatty acid metabolism in freshwater fish with particular reference to polyunsaturated fatty acids. Arch. Animal Nutr. 49, 5-22. doi: 10.1080/17450399609381859

Hossain, M. S., Peng, M., and Small, B. C. (2021). Optimizing the fatty acid profile of novel terrestrial oil blends in low fishmeal diets of rainbow trout (Oncorhynchus mykiss) yields comparable fish growth, total fillet n-3 LC-PUFA content, and health performance relative to fish oil. Aquaculture. 545, 737230. doi: 10.1016/j.aquaculture.2021.737230 
Kaur, G., Guo, X. F., and Sinclair, A. J. (2016). Short update on docosapentaenoic acid: a bioactive long-chain n-3 fatty acid. Curr. Opin. Clin. Nutr. Metabol. Care. 19, 88-91. doi: 10.1097/MCO.0000000000000252

Koven, W., Barr, Y., Lutzky, S., Ben-Atia, I., Weiss, R., Harel, M., et al. (2001). The effect of dietary arachidonic acid (20: $4 \mathrm{n}-6)$ on growth, survival and resistance to handling stress in gilthead seabream (Sparus aurata) larvae. Aquaculture. 193, 107-122. doi: 10.1016/S0044-8486(00)00479-8

Koven, W., van Anholt, R., Lutzky, S., Atia, I. B., Nixon, O., Ron, B., et al. (2003). The effect of dietary arachidonic acid on growth, survival, and cortisol levels in different-age gilthead seabream larvae (Sparus auratus) exposed to handling or daily salinity change. Aquaculture. 228, 307-320. doi: 10.1016/S0044-8486(03)00317-X

Kowalska, A., and Kowalski, R. K. (2014). The effect of cyclooxygenase (COX) inhibitors on Japanese medaka (Oryzias latipes) reproduction parameters fed with high level of arachidonic acid (20: 4 n-6). Aquac. Int. 22, 185-193. doi: 10.1007/s10499-013-9684-z

Li, L., Cardoso, J. C., Félix, R. C., Mateus, A. P., Canário, A. V., and Power, D. M. (2021). Fish lysozyme gene family evolution and divergent function in early development. Develop. Compar. Immunol. 114, 103772. doi: 10.1016/j.dci.2020.103772

Li, Y., Monroig, O., Zhang, L., Wang, S., Zheng, X., Dick, J. R., et al. (2010). Vertebrate fatty acyl desaturase with $\Delta 4$ activity. Proc. Nat. Acad. Sci. 107, 16840-16845. doi: 10.1073/pnas.1008429107

Lozano-Muñoz, I., Muñoz, S., Díaz, N. F., Medina, A., Bazaes, J., and Riquelme, C. (2020). Nutritional enhancement of farmed salmon meat via nonGMO Nannochloropsis gaditana: eicosapentaenoic acid (EPA, 20: 5 n-3), docosapentaenoic acid (DPA, 22: 5 n-3) and Vitamin D3 for human health. Molecules. 25, 4615. doi: 10.3390/molecules25204615

Martins, D. A., Rocha, F., Castanheira, F., Mendes, A., Pousão-Ferreira, P., Bandarra, N., et al. (2013). Effects of dietary arachidonic acid on cortisol production and gene expression in stress response in Senegalese sole (Solea senegalensis) post-larvae. Fish Physiol. Biochem. 39, 1223-1238. doi: 10.1007/s10695-013-9778-6

Montero, D., Robaina, L., Caballero, M. J., Gines, R., and Izquierdo, M. S. (2005). Growth, feed utilization and flesh quality of European sea bass (Dicentrarchus labrax) fed diets containing vegetable oils: A time-course study on the effect of a re-feeding period with a $100 \%$ fish oil diet. Aquaculture. 248, 121-134. doi: 10.1016/j.aquaculture.2005.03.003

Morais, S., Castanheira, F., Martinez-Rubio, L., Conceição, L. E., and Tocher, D. R. (2012). Long chain polyunsaturated fatty acid synthesis in a marine vertebrate: ontogenetic and nutritional regulation of a fatty acyl desaturase with $\triangle 4$ activity. Biochimica et Biophysica Acta (BBA)-Molec. Cell Biol. Lipid. 1821, 660-671. doi: 10.1016/j.bbalip.2011.12.011

Morais, S., Knoll-Gellida, A., André, M., Barthe, C., and Babin, P. J. (2007). Conserved expression of alternative splicing variants of peroxisomal acyl-CoA oxidase 1 in vertebrates and developmental and nutritional regulation in fish. Physiol. Genom. 28, 239-252. doi: 10.1152/physiolgenomics.00136.2006

Napier, J. A., Olsen, R. E., and Tocher, D. R. (2019). Update on GM canola crops as novel sources of omega-3 fish oils. Plant Biotechnol. J. 17, 703. doi: $10.1111 /$ pbi. 13045

Norambuena, F., Morais, S., Emery, J. A., and Turchini, G. M. (2015). Arachidonic acid and eicosapentaenoic acid metabolism in juvenile Atlantic salmon as affected by water temperature. PLoS ONE. 10, e0143622. doi: 10.1371 /journal.pone. 0143622

NRC (National Research Council), (2011). Nutrient Requirements of Fish and Shrimp. National Academy Press, Washington, DC, p. 376.

Osmond, A. T., and Colombo, S. M. (2019). The future of genetic engineering to provide essential dietary nutrients and improve growth performance in aquaculture: advantages and challenges. $J$ World Aquac Soc. 50, 490-509. doi: $10.1111 /$ jwas. 12595

Overturf, K., Welker, T., Barrows, F., Towner, R., Schneider, R., and LaPatra, S. (2013). Variation in rainbow trout, Oncorhynchus mykiss, to biosynthesize eicosapentaenoic acid and docosahexaenoic acid when reared on plant oil replacement feeds. J. World Aquacult. Soc. 44, 326-337. doi: 10.1111/jwas.12041

Pfaffl, M. W. (2001). A new mathematical model for relative quantification in real-time RT-PCR. Nucl. Acids Res. 29, e45. doi: 10.1093/nar/29.9.e45

Qi, C. L., Zhao, S. Y., Xiao-Hong, T., Niu, J., Wang, J., Wang, Y., et al. (2016). Effects of dietary arachidonic acid levels on growth performance, whole-body proximate composition, digestive enzyme activities and gut morphology of juvenile golden pompano trachinotus. Israeli J. Aquacult. Bamidgeh. 68, 20819. doi: 10.46989/001c.20819

Rombenso, A. N., Trushenski, J. T., Jirsa, D., and Drawbridge, M. (2016). Docosahexaenoic acid (DHA) and arachidonic acid (ARA) are essential to meet LC-PUFA requirements of juvenile California Yellowtail (Seriola dorsalis). Aquaculture. 463, 123-134. doi: 10.1016/j.aquaculture.2016.05.004

Sakin, F., Ispir, U., Yonar, S. M., Yonar, M. E., and Taysi, M. R. (2011). Effect of short-term cypermethrin exposure on oxidant-antioxidant balance in the whole body of rainbow trout fry (Oncorhynchus mykiss). Fresen. Environ. Bull. 20, 2806-2809.

Samuelsson, B. (1983). Leukotrienes: mediators of immediate hypersensitivity reactions and inflammation. Science. 220, 568-575. doi: $10.1126 /$ science.6301011

Schrader, M., and Fahimi, H. D. (2006). Peroxisomes and oxidative stress. Biochim. Biophys. Acta (BBA)-Molec. Cell Res. 1763, 1755-1766. doi: 10.1016/j.bbamcr.2006.09.006

Simopoulos, A. P. (2000). Human requirement for $\mathrm{N}-3$ polyunsaturated fatty acids. Poultry Sci. 79, 961-970. doi: 10.1093/ps/79.7.961

Sprecher, H. (2000). Metabolism of highly unsaturated n-3 and n-6 fatty acids. Biochem. Biophys. Acta. 1486, 219-231. doi: 10.1016/S1388-1981(00)00077-9

Thanuthong, T., Francis, D. S., Manickam, E., Senadheera, S. D., CameronSmith, D., and Turchini, G. M. (2011). Fish oil replacement in rainbow trout diets and total dietary PUFA content: II Effects on fatty acid metabolism and in vivo fatty acid bioconversion. Aquaculture. 322, 99-108. doi: 10.1016/j.aquaculture.2011.09.026

Tocher, D. (2009). Issues surrounding fish as a source of omega-3 long-chain polyunsaturated fatty acids. Lipid Technol. 21, 13-16. doi: 10.1002/lite.200800079

Tocher, D. R. (2015). Omega-3 long-chain polyunsaturated fatty acids and aquaculture in perspective. Aquacult. 449, 94-107. doi: 10.1016/j.aquaculture.2015.01.010

Tocher, D. R., Betancor, M. B., Sprague, M., Olsen, R. E., and Napier, J. A. (2019). Omega-3 long-chain polyunsaturated fatty acids, EPA and DHA: bridging the gap between supply and demand. Nutrients. 11, 89. doi: 10.3390/nu110 10089

Torrecillas, S., Betancor, M. B., Caballero, M. J., Rivero, F., Robaina, L., Izquierdo, M., et al. (2018). Supplementation of arachidonic acid rich oil in European sea bass juveniles (Dicentrarchus labrax) diets: effects on growth performance, tissue fatty acid profile and lipid metabolism. Fish Physiol. Biochem. 44, 283-300. doi: 10.1007/s10695-017-0433-5

Turchini, G. M., Torstensen, B. E., and Ng, W. K. (2009). Fish oil replacement in finfish nutrition. Rev. Aquacult. 1, 10-57. doi: $10.1111 / j .1753-5131.2008 .01001 . x$

Weatherup, R. N., and McCracken, K. J. (1999). Changes in Rainbow Trout, Oncorhynchus Mykiss. (Walbaum), body composition with weight. doi: 10.1046/j.1365-2109.1999.00320.x

Xu, H., Ai, Q., Mai, K., Xu, W., Wang, J., Ma, H., et al. (2010). Effects of dietary arachidonic acid on growth performance, survival, immune response and tissue fatty acid composition of juvenile Japanese seabass, Lateolabrax japonicus. Aquaculture. 307, 75-82. doi: 10.1016/j.aquaculture.2010.07.001

Xu, H., Cao, L., Zhang, Y., Johnson, R. B., Wei, Y., Zheng, K., et al. (2017). Dietary arachidonic acid differentially regulates the gonadal steroidogenesis in the marine teleost, tongue sole (Cynoglossus semilaevis), depending on fish gender and maturation stage. Aquaculture. 468, 378-385. doi: 10.1016/j.aquaculture.2016.11.002

Ytrestøyl, T., Aas, T. S., and Åsgård, T. (2015). Utilisation of feed resources in production of Atlantic salmon (Salmo salar) in Norway. Aquaculture. 448, 365-374. doi: 10.1016/j.aquaculture.2015.06.023

Yu, G., Ou, W., Liao, Z., Xu, H., Liang, M., Zhang, Y., et al. (2019). Intestinal homeostasis of juvenile tiger puffer Takifugu rubripes was sensitive to dietary arachidonic acid in terms of mucosal barrier and microbiota. Aquaculture. 502, 97-106. doi: 10.1016/j.aquaculture.2018.12.020

Yuan, Y., Li, S., Mai, K., Xu, W., Zhang, Y., and Ai, Q. (2015). The effect of dietary arachidonic acid (ARA) on growth performance, fatty acid composition and expression of ARA metabolism-related genes in larval halfsmooth tongue sole (Cynoglossus semilaevis). Br. J. Nutr. 113, 1518-1530 doi: $10.1017 /$ S0007114515000781 
Conflict of Interest: DI was employed by Cargill Incorporated.

The remaining authors declare that the research was conducted in the absence of any commercial or financial relationships that could be construed asa potential conflict of interest.

Publisher's Note: All claims expressed in this article are solely those of the authors and do not necessarily represent those of their affiliated organizations, or those of the publisher, the editors and the reviewers. Any product that may be evaluated in this article, or claim that may be made by its manufacturer, is not guaranteed or endorsed by the publisher.

Copyright $\odot 2022$ Hong, Bledsoe, Overturf, Lee, Iassonova and Small. This is an open-access article distributed under the terms of the Creative Commons Attribution License (CC BY). The use, distribution or reproduction in other forums is permitted, provided the original author(s) and the copyright owner(s) are credited and that the original publication in this journal is cited, in accordance with accepted academic practice. No use, distribution or reproduction is permitted which does not comply with these terms. 